\title{
Storm-influenced deposition and cyclicity in a shallow-marine mudstone succession - example from the Middle Jurassic ore-bearing clays of the Polish Jura (southern Poland)
}

\author{
Paulina LEONOWICZ ${ }^{1, *}$
}

1 University of Warsaw, Institute of Geology, Żwirki i Wigury 93, 02-089 Warszawa, Poland

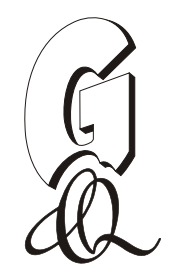

\begin{abstract}
Leonowicz, P., 2015. Storm-influenced deposition and cyclicity in a shallow-marine mudstone succession - example from the Middle Jurassic ore-bearing clays of the Polish Jura (southern Poland). Geological Quarterly, 59 (2): 325-344, doi: 10.7306/gq.1221

Sedimentological analysis of bioturbated mudstones from the Middle Jurassic ore-bearing Częstochowa Clay Formation has revealed common relics of sedimentary structures, such as thin silt/sand laminae, bedding-plane accumulations of shell debris, small and medium silt-sand lenses, as well as silt-, sand- and shell-debris-rich levels, accompanied by erosion surfaces and minor scours. These features document periodical high-energy conditions of mud deposition, including storm stirring, event sedimentation and the activity of storm-generated bottom currents, which were responsible for sea-floor erosion and sediment supply from shallower parts of the basin. The sea bottom was prevalently below the storm wave base, but it rose above it during exceptionally strong storms and in the Early Bathonian zigzag chron when the basin experienced considerable shallowing. The shallowest and highest energy conditions occurred in the late macrescens subchron, when the bottom was close to, or above the fair-weather wave base. The estimated depth of the sea did not exceed several tens of metres, but in some periods it could be even less than $20 \mathrm{~m}$. Based on the vertical variation of the sand, silt and clay contents, seven transgressive-regressive cycles have been distinguished in the approximately $75 \mathrm{~m}$ thick succession spanning the Upper Bajocian-Upper Bathonian. Cycles $\mathrm{TR}_{1}, \mathrm{TR}_{2+3}, \mathrm{TR}_{5}$ and $\mathrm{TR}_{6+7}$ correlate with those distinguished in the coeval succession from central Poland, although the stratigraphic position of cycle boundaries is slightly shifted. These cycles record relative sea level changes that affected the entire Polish Basin. Regressions $R_{2}$ and $R_{6}$ were smaller-scale-events, generated in response to a local tectonic activity and autocyclic shoreline progradation.
\end{abstract}

Key words: bioturbated mudstones, storm deposits, transgressive-regressive cycles, ore-bearing Częstochowa Clay Formation, Silesian-Cracow region.

\section{INTRODUCTION}

Sedimentological investigation of mudstones and shales is substantially impeded by their fine grain size and resultant homogeneous appearance. Because of the lack of well-visible sedimentary structures they have long been considered to represent the products of stable, continuous deposition in quiet bottom-water conditions. Recent studies of modern and ancient muddy deposits, based on the careful examination of millimetre to centimetre-scale sedimentary structures (e.g., Pedersen, 1985; Wignall, 1989; Schieber, 1990, 1994, 1999; O’Brien, 1996), combined with laboratory investigations carried out by Schieber and his co-workers (Schieber et al., 2007, 2010; Schieber and Southard, 2009; Schieber and Yawar, 2009), have proved that mud can accumulate in a wide range of environments ranging from the high-energy nearshore to the deep

\section{*E-mail: Paulina.Leonowicz@uw.edu.pl}

Received: April 3, 2014; accepted: January 24, 2015; first published online: February 16, 2015 ocean floor. Several of these aspects are addressed in this paper, which focuses on a Middle Jurassic muddy epicontinental-shelf succession, referred to as the ore-bearing Częstochowa Clay Formation. This formation, known also as the ore-bearing clays, crops out in the central part of the Silesian-Cracow Upland, southern Poland (Fig. 1), and consists of dark grey organic-rich, calcareous mudstones, intercalated with siderite and calcareous concretions, and rare sandstones (Dayczak-Calikowska and Kopik, 1973).

The mudrocks of the ore-bearing Częstochowa Clay Formation fall into two facies varieties, one represented by intensely bioturbated mudstones, containing a diverse association of benthic fauna, and the other composed of well-laminated mudstones with rare benthic fauna (Leonowicz, 2012, 2013). Because the bioturbated facies dominates in the outcrops, there are few sedimentological accounts that are based mainly on indistinct relicts of primary sedimentary structures (Merta and Drewniak, 1998; Leonowicz, 2012). Hence, palaeoenvironmental interpretations of the ore-bearing clays are based mostly on palaeontological, geochemical and petrological investigations (for summary, see Zatoń et al., 2009; Zatoń, 2011). The range of inferred settings varies from a shallow to very shallow marine (Garbowska et al., 1978; Smoleń, 2006), open marine to estuarine (Merta and Drewniak, 1998), and from 


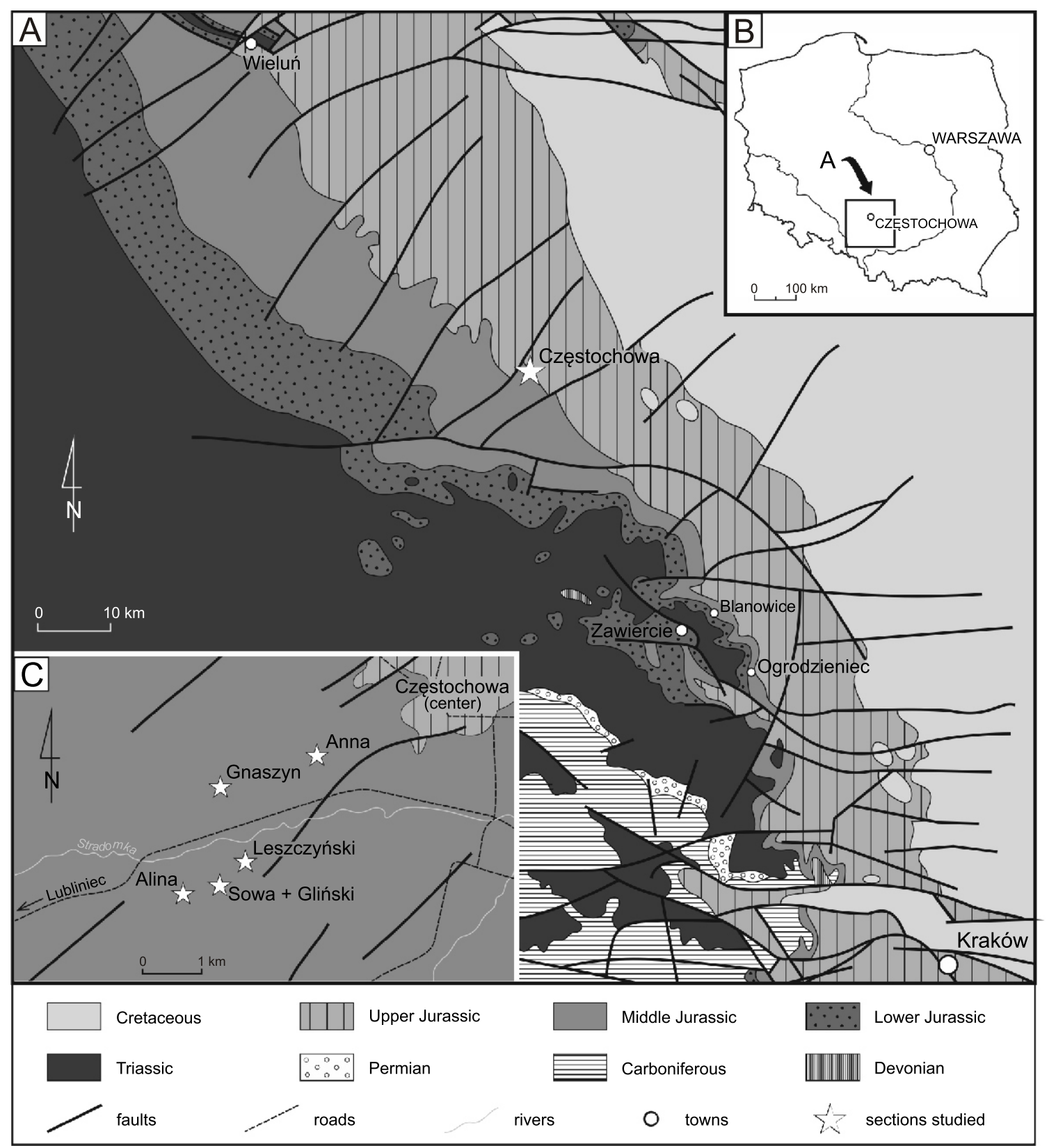

Fig. 1A - geological map of the Silesian-Cracow Upland (after Dadlez et al., 2000, simplified) and location of the succession studied; B - area shown on map A; C - location of the clay-pit sections on the geological sketch map of the western part of town of Częstochowa (after Lewandowski, 1986, modified)

an open shallow sea below the storm wave base (Gedl et al., 2006a, b, c; Leonowicz, 2012) to the outer shelf periodically shallowing into the high-energy subtidal environment (Zatoń et al., 2011). Gedl et al. (2012), based on micropalaeontological and mineralogical data, suggested a water depth ranging from several tens to a few hundred metres. The detailed sedimentological study of the laminated mudstones led the present author (Leonowicz, 2013) to suggest they were deposited below the storm wave base from storm-generated bottom currents, which redistributed significant amounts of sediment from shallow-water areas.

Many authors who have studied the ore-bearing clays suggest a fluctuation of depositional conditions linked to the sea level changes. Garbowska et al. (1978) presented lithological and micropalaeontological characteristics of two drill cores and distinguished two cyclothems: Upper Bajocian-Lower Bathonian and Middle-Upper Bathonian, each recording shallowing of the sea. Based on ammonoid diversity, Zatoń (2011) indicated three bio-events falling into the latest Bajocian, Early Bathonian and Late Bathonian, which he related to transgressive episodes. Gedl et al. (2012), based mainly on the analysis of microfossils, palynofacies and sporomorphs, distinguished four phases of sea level rise in the Middle-Upper Bathonian succession from Częstochowa, three in the Middle Bathonian and one in the Upper Bathonian. In the same succession, Leonowicz (2012) noted several intervals enriched in ammonite remains, which document periods of reduced sedimentation rate. Despite the substantial progress in understanding sedimentary environments, the ore-bearing clays still lack a sufficient sedimentological background that would allow subdi- 
viding the entire succession in terms of transgressive-regressive cycles. The present paper partly fills this gap and provides the results of detailed sedimentological study of the bioturbated mudstone facies in the most completely exposed and stratigraphically well-dated succession from the central part of the outcrop belt.

\section{PALAEOGEOGRAPHICAL AND GEOLOGICAL BACKGROUND}

During the Mesozoic most of the territory of Poland was part of an extensive system of epicontinental seas, called the Central European Basin System (CEBS), which covered a vast area of Central Europe. In Middle Jurassic time, intense tectonic activity in the North Sea area led to the internal differentiation of the CEBS into a number of basins (Pieńkowski et al., 2008). The Polish Basin constituted the easternmost arm of the CEBS, distant from the tectonically active zone and surrounded largely by lands (Fig. 2). The important tectonic element of this basin was a narrow, NW-SE oriented, axial zone, called the Mid-Polish Trough (MPT). This zone experienced considerable subsidence resulting in the accumulation of a sediment succession exceeding $1000 \mathrm{~m}$ in thickness (Dayczak-Calikowska and Moryc, 1988; Feldman-Olszewska, 1997; Pieńkowski et al., 2008). Outside this zone, the thickness decreases to $300 \mathrm{~m}$ and the succession reveals several hiatuses. The origin and tectonic character of the MPT is not clear. Kutek (1994) defined it as a continental rift. Dadlez et al. (1995) suggested that the de-

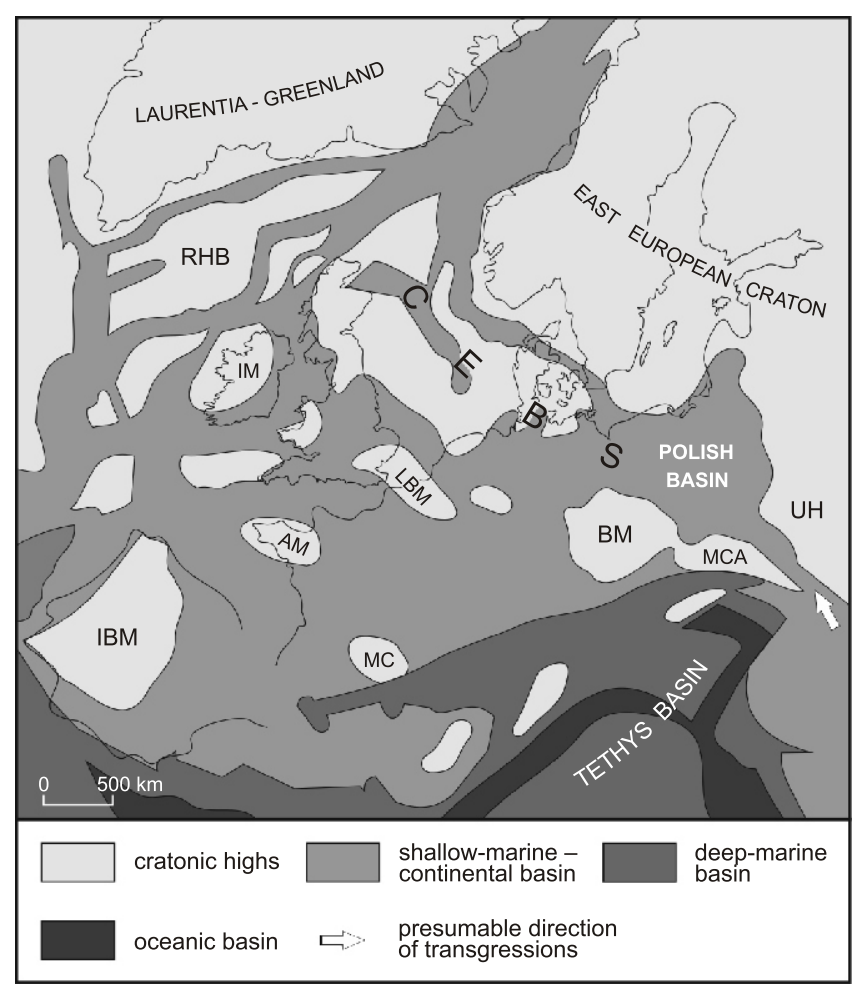

Fig. 2. Palaeogeographical map of Europe in the Middle Jurassic (modified after Ziegler, 1990)

AM - Armorican Massif, BM - Bohemian Massif, CEBS - Central European Basin System, IBM - Iberian Meseta, IM - Irish Massif, LBM - London-Brabant Massif, MC - Massif Central High, MCA Meta-Carpathian Arc, RHB - Rockall-Hatton Bank, UH - Ukrainian High velopment of the MPT was characterized by extensional and compressional phases linked with the tectonic evolution of the Tethys and the Atlantic. Dadlez (2003) explained increased subsidence of this zone by the activity of deep-seated sub-Zechstein faults, whose upward propagation was hindered by the plastic nature of Zechstein salts. The boundaries of the MPT were controlled by periodically active syndepositional faults of limited extent that are recorded by thickness contrasts (Feldman-Olszewska, 1997; Dadlez, 2003). Transverse faults and movements of salt structures, leading to the differentiation of basin bottom into several elevations and depocentres (Dadlez, 1994; Feldman-Olszewska, 1997; Pieńkowski et al., 2008), also influenced the sedimentation.

In the Middle Jurassic, the communication of the Polish Basin with other Central European seas was limited and deposition was influenced mainly by the Tethyan regime (Pieńkowski et al., 2008). It was a time of gradual marine transgression in the Polish Basin, interrupted by short-lived regressions and stillstand periods (e.g., Matyja and Wierzbowski, 2006a; Pieńkowski et al., 2008). Pieńkowski et al. (2008) distinguished eight transgressive-regressive cycles in the Middle Jurassic succession from central Poland. Transgressions entered most probably from the south-east, through the East Carpathian Gate (Dayczak-Calikowska, 1997) that connected the Polish Basin with the Tethyan ocean. Initially, marine sedimentation was limited to the MPT (Fig. 3A; Feldman-Olszewska, 1998; Pieńkowski et al., 2008). In the Early Bajocian, the sea extended outside this zone and split into two branches separated by an elongated elevation, called the Wielkopolska Ridge (Fig. 3A; Feldman-Olszewska, 1997). This elevation occurred in topography as a peninsula during regressions and as a submarine sill during transgressions until the Early Bathonian, when it was finally flooded (Feldman-Olszewska, 1997). Since that time, the sea extended gradually to the north-east and south-west and the progress of transgression continued during the Late Jurassic.

The Silesian-Cracow area was situated in the south-western, marginal part of the Polish Basin (Fig. 3), which belonged to the southwestern branch of the basin in the early Middle Jurassic. It was surrounded by lands: Bohemian Massif, Małopolska Land and Wielkopolska Ridge (Dayczak-Calikowska and Moryc, 1988; Feldman-Olszewska 1997, 1998), which served as source areas of clastic material. The position of the southwestern boundary of the basin is problematic because of the lack of deposits that were removed during the Cenozoic, so that the present-day western boundary of Jurassic deposits is erosional. The marine transgressions most probably approached from the Mid-Polish Through, entering the Silesian-Cracow area from the north-east and expanded to the north-west, west and south-east. For the first time the Silesian-Cracow region was flooded in the Early Bajocian sauzei chron (Kopik, 1998). After a short regression in the subfurcatum chron, the sea returned to this area in the Late Bajocian garantiana chron (Kopik, 1998). Since that time, marine sedimentation lasted without significant breaks until the end of Middle Jurassic (Barski et al., 2004) and continued during the Late Jurassic. During the Bathonian, after the flooding of the Wielkopolska Ridge, the sea extended gradually towards the south-west (Fig. 3B) but probably did not flood over the Bohemian Massif until the end of Middle Jurassic (Feldman-Olszewska, 1997).

The Middle Jurassic succession of the Silesian-Cracow area (Fig. 4) starts with Upper Bajocian sandy deposits of the Kościelisko Beds (sauzei-humphriesianum zones), resting with a stratigraphic hiatus on older Mesozoic rocks (Kopik, 1997, 1998). They are overlain by a thick muddy complex of the Upper Bajocian-Upper Bathonian (garantiana-discus zones) 


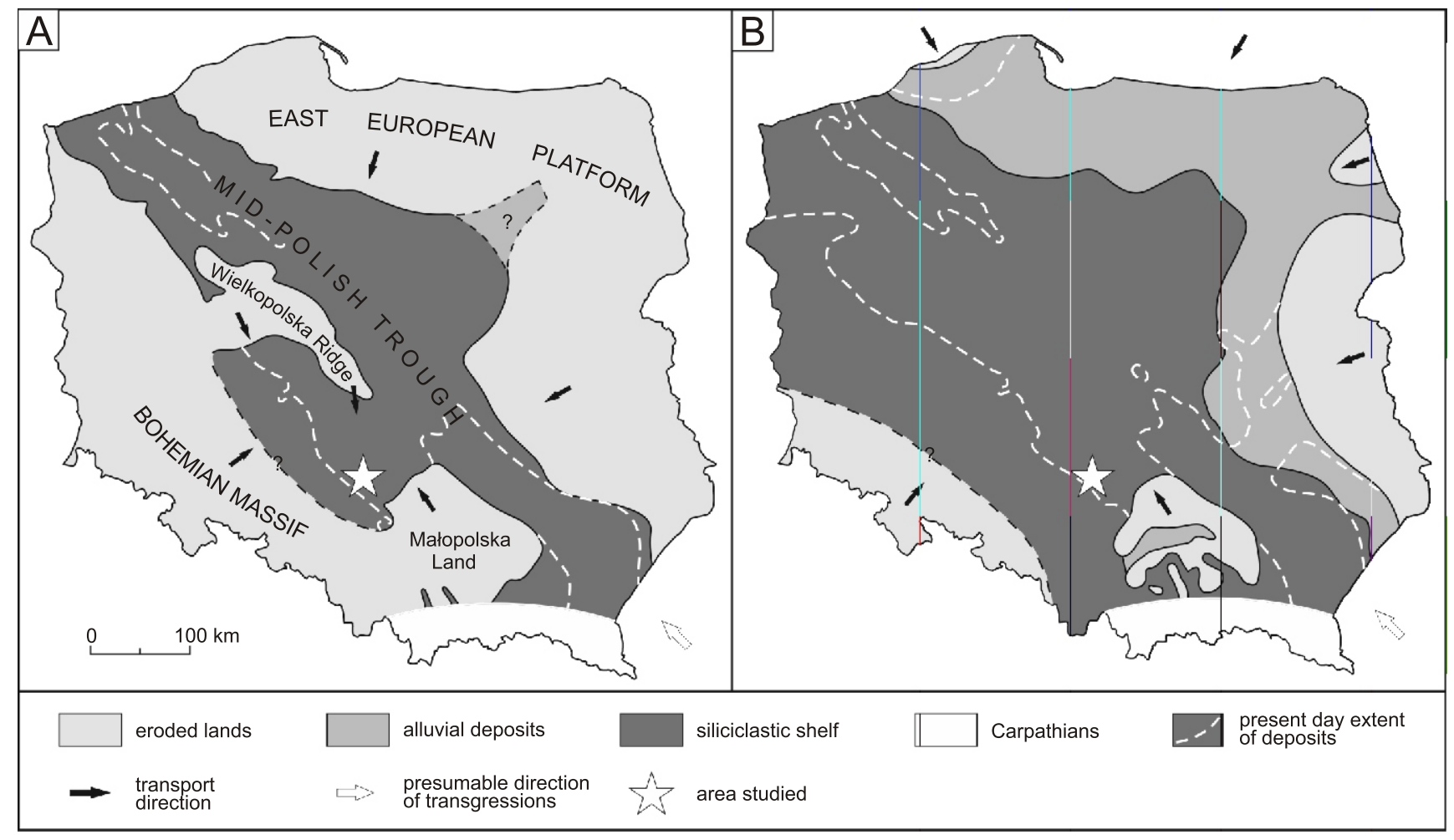

Fig. 3. Polish Basin during the Middle Jurassic (modified after Feldman-Olszewska, 1998) and the location of the study area

\section{A - Early Bathonian convergens chron; B - Middle Bathonian bremeri chron}

ore-bearing Częstochowa Clay Formation (Kopik, 1998; Matyja and Wierzbowski, 2000, 2006b; Barski et al., 2004), which in turn, passes upwards into condensed Callovian deposits (Kopik, 1997). The thickness of ore-bearing clays reaches its maximum value of about $200 \mathrm{~m}$ north of Częstochowa (Kopik, 1997). To the south, it gradually decreases and south of Zawiercie the ore-bearing clays wedge out and pass into various shallow marine clastic and calcareous deposits (Kopik, 1997). The present study concerns deposits exposed in five active clay-pits in Częstochowa: Alina, Sowa + Gliński, Leszczyński, Gnaszyn and Anna (Fig. 1C). These exposures span the Upper Bajocian parkinsoni zone to the Upper Bathonian retrocostatum zone (Matyja and Wierzbowski, 2003, 2006b). However, three sections from the older part of the succession do not overlap, thus the total succession studied is not complete (Fig. 4).

\section{METHODS}

The deposits exposed in clay-pits were examined centimetre by centimetre, taking into account the lithology, sedimentary structures, bioturbation and benthic fauna. Special attention was paid to biodeformational structures defined as burrows with indistinct outlines (Wetzel, 1991). They were divided into three groups: large - structures $1 \mathrm{~cm}$ and more across, well discernible during outcrop examination; medium - a few millimetres across, also recognizable in outcrops; and small - comprising cryptobioturbation (sensu Pemberton et al., 2008). The latter are too small to be visible during outcrop examination, but they blur the boundaries of sedimentary structures, may destroy thin laminae and homogenize the sediment. Among benthic fauna, special attention was paid to deeply burrowing bi- valves and their position within the sediment. Sedimentary and biogenic structures were observed only in unweathered parts of sections. To recognize lithological changes within the monotonous mudstone succession, 68 samples were subjected to grain-size analysis by areometry and dry sieving to evaluate the contents of sand, silt and clay (Fig. 4). The values of bounding sizes follow the Udden-Wentworth scale (fide McManus, 1988).

\section{RESULTS AND INTERPRETATION}

\section{SEDIMENTARY STRUCTURES}

Sedimentary structures and their relics, preserved locally in bioturbated mudstones from Częstochowa, represent prevalently various kinds of horizontal lamination. Most of them were observed also in laminated mudstones of the same formation exposed near Zawiercie (Leonowicz, 2013). The latter serve as a point of reference in interpretation of the origin of structures studied, the internal features of which are partly obliterated by benthic activity. They are described below in order from the thinnest and most subtle to the thickest. Their distribution in the succession is presented in Figure 5.

\section{PARALLEL STRIPES}

Observations. On surfaces perpendicular to the bedding planes, these appear as thin, indistinct parallel streaks, which show subtle colour variations from dark to light grey. Light grey stripes contain admixture of fine quartz and/or shell debris, whereas dark grey ones are rich in clay. On parting planes, the stripes appear as flat, horizontally oriented patches of irregular shape. The fabric of clay-rich mudstones consists of silt-rich 


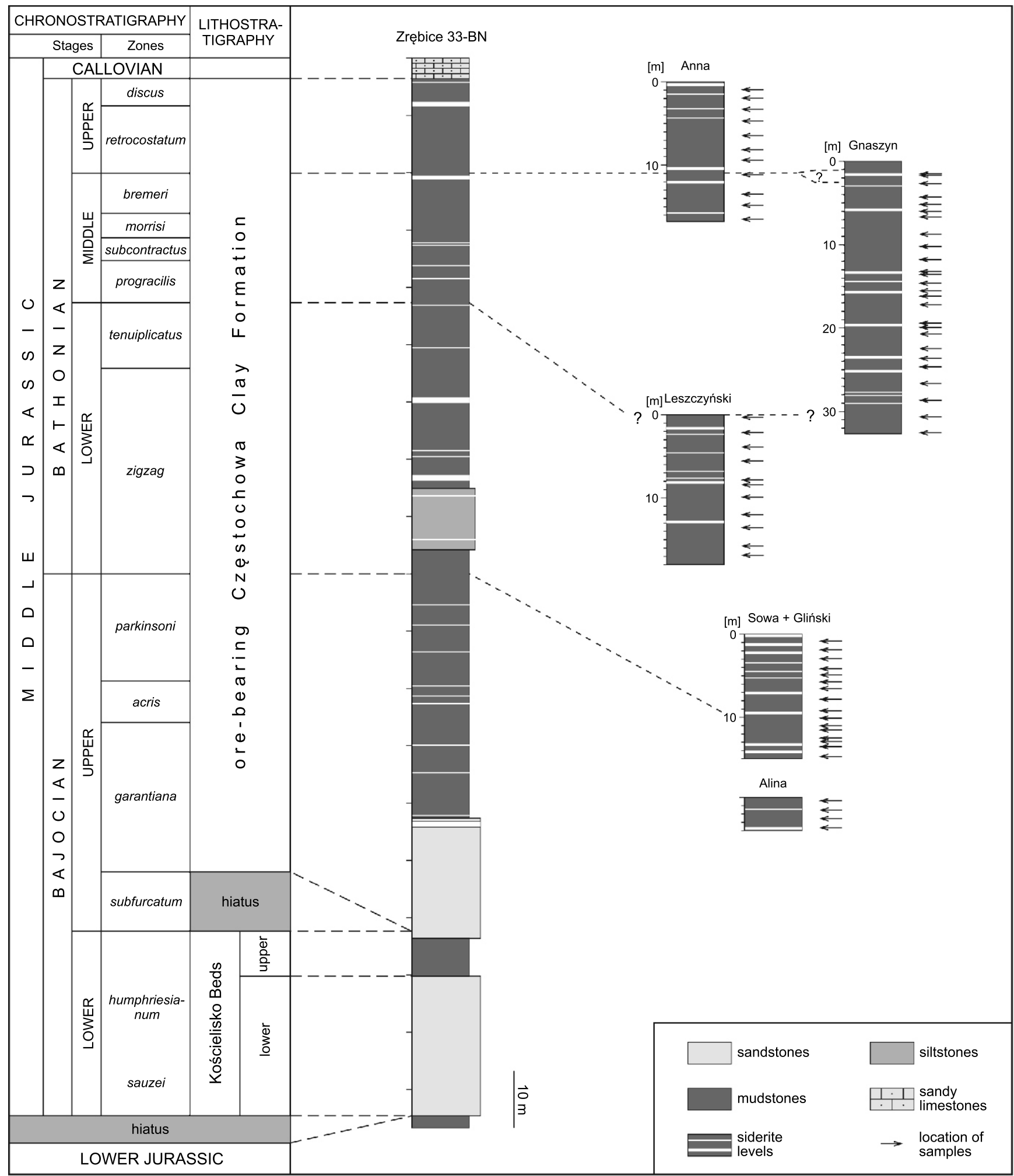

Fig. 4. Stratigraphy of Middle Jurassic deposits from the Silesian-Cracow region (after Kopik, 1998; Matyja and Wierzbowski, 2000, 2006b; Barski et al., 2004) and a representative section of the Zrębice 33-BN borehole (stratigraphy after Kopik, 1998)

To the right are shown sections studied in greater detail and the location of samples selected for grain-size analysis (generalized stratigraphy after Matyja and Wierzbowski, 2000, 2003, 2006b) 


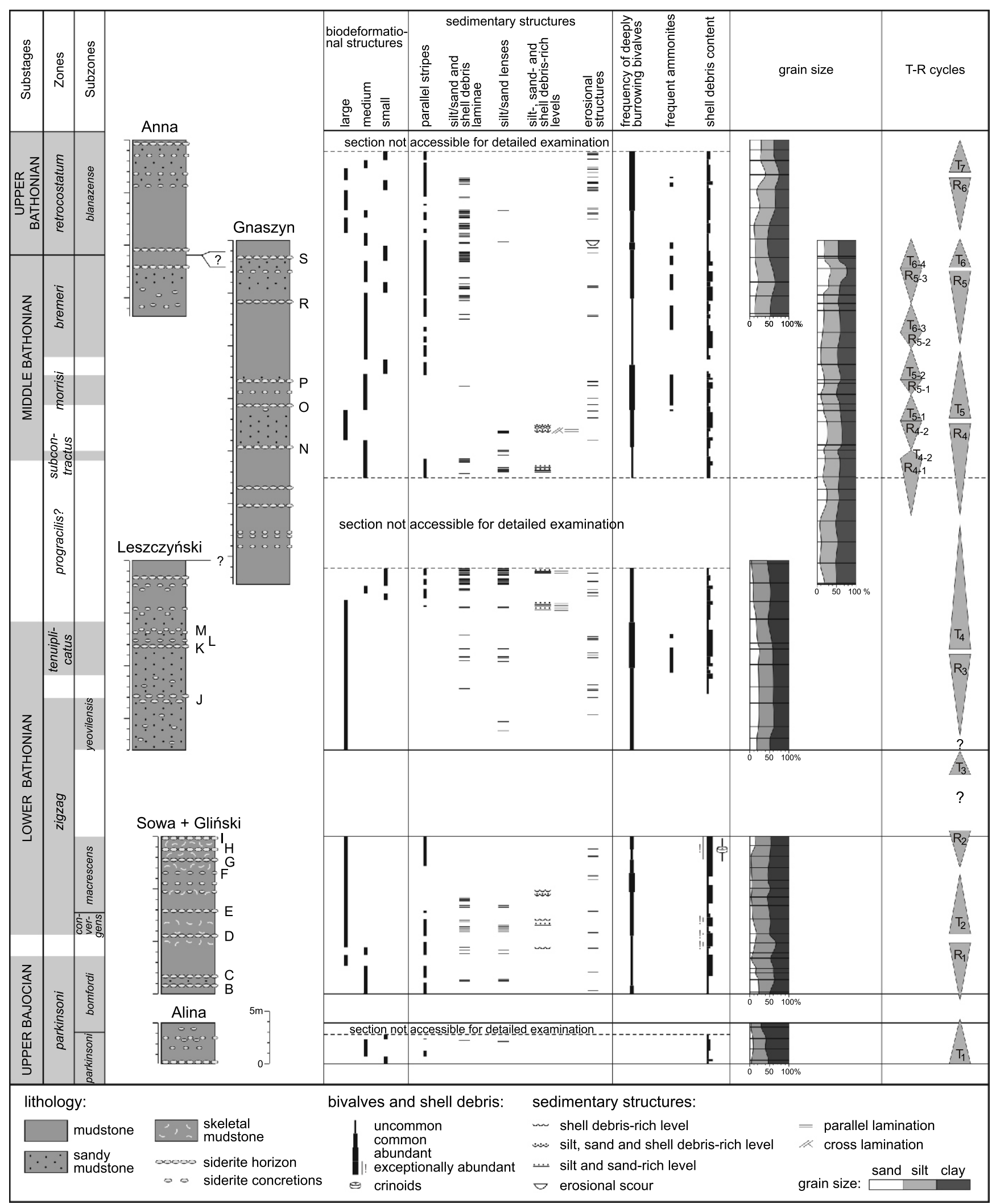

Fig. 5. Lithological logs of ore-bearing mudstones from outcrops in Częstochowa, showing distribution of sedimentary and biodeformational structures, frequency of shell debris and deeply burrowing bivalves, intervals with common ammonites and grain-size composition

To the right, interpretation of transgressive-regressive (T-R) cycles is presented;

biostratigraphy and numbering of siderite horizons (B-S) after Matyja and Wierzbowski (2000, 2003, 2006b) 

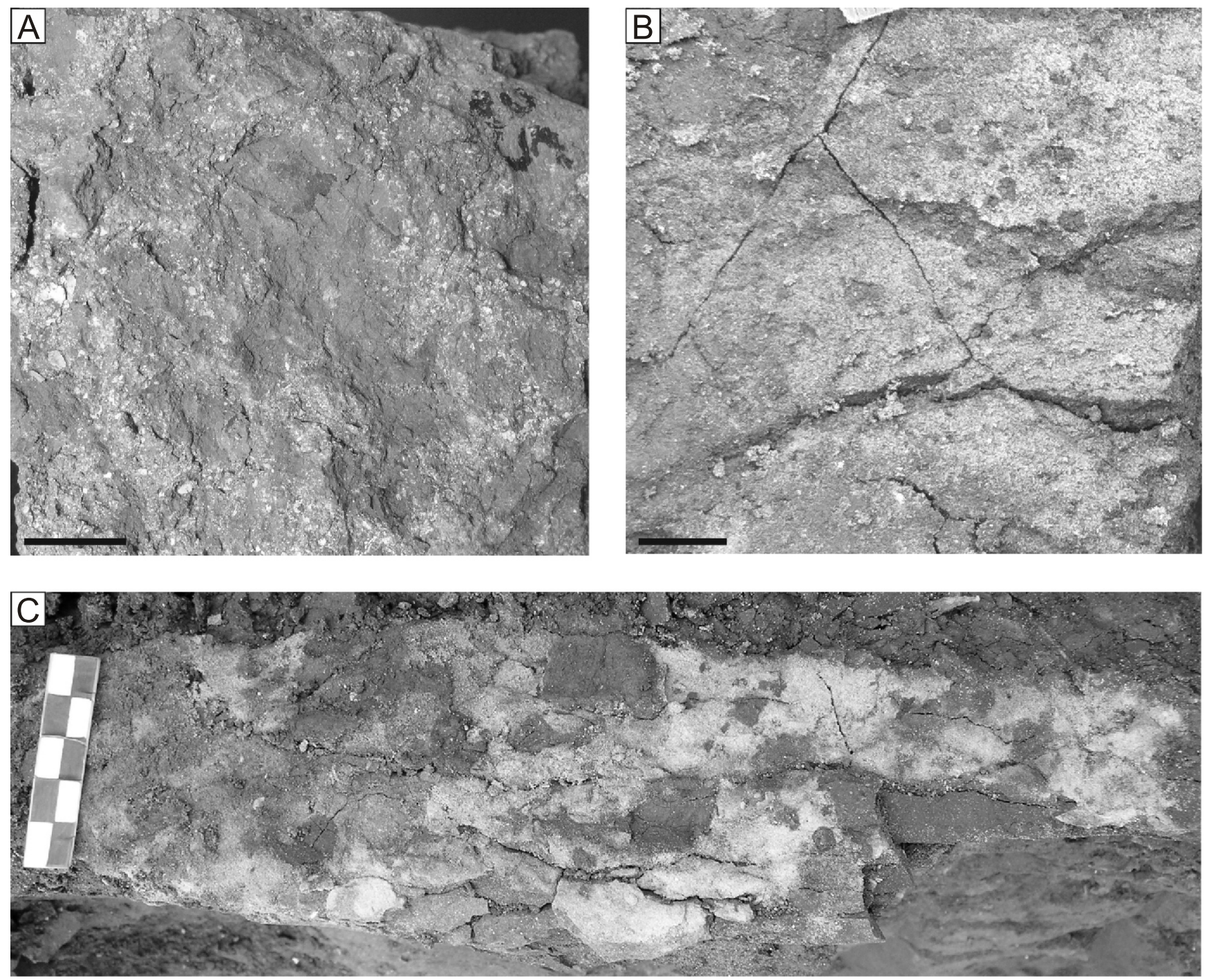

Fig. 6. Sedimentary structures from bioturbated mudstones of ore-bearing clays

A - parallel stripes: irregular patches of dark grey mudstone within light grey shell-debris-rich background sediment; parting plane view; B thin silt/sand lamina: view on the upper surface cut by Chondrites (dark dots); $\mathbf{C}$ - medium-sized silt/sand lens: view on exposed basal part with several dark grey clay-chips; parting plane view; A - Gliński clay-pit, B, C - Gnaszyn clay-pit; scale bar in A and B is $1 \mathrm{~cm}$, scale bar in C is in centimetres (photo B by A. Uchman)

patches, usually $<1 \mathrm{~mm}$ thick and several millimetres wide, occurring within structureless clay. Deposits rich in shell debris and sand material, contain clayey patches reaching 1-2 cm across, appearing among coarser-grained background deposits (Fig. 6A). Shell debris may be dispersed uniformly or concentrate in elongated zones, several centimetres long and $>1 \mathrm{~cm}$ wide, which are most likely bioturbation structures. Parallel stripes occur commonly almost in the entire succession (Fig. 5), producing an effect of the vague parallel-orientated fabric of mudstones. This effect is often enhanced by horizontal orientation of trace fossils, mainly Chondrites and other undetermined biodeformational structures.

Interpretation. The fabric consisting of indistinct paralle stripes was observed in laminated mudstones from the Zawiercie area and interpreted as the product of moderate cryptobioturbation of laminated deposits containing fine silt-sand laminae (Leonowicz, 2013). It is likely that the parallel-orientated fabric of mudstones from Częstochowa has a similar origin and resulted from incomplete biogenic disruption of primary horizontal stratification. Burrowing animals might have various sizes, ranging from meiofauna (up to $1 \mathrm{~mm}$ ) to relatively large organisms that produced burrows $>1 \mathrm{~cm}$ across. Original stratification consisted, as in the Zawiercie area, of silt-sand laminae and accumulations of comminuted shell debris. The amount and thickness of these laminae varied in the succession, resulting in a different lithology of mudstones (clay-rich vs. shell-debris-rich and sand-rich mudstones).

SILT/SAND LAMINAE

Observations. These are thin, $<1 \mathrm{~mm}$ thick, horizontal, discontinuous accumulations of quartz silt and very fine sand (Fig. 6B). Laterally, they disappear among bioturbated zones. The lateral extent of these laminae varies from $2 \mathrm{~cm}$ to several decimetres. Silt/sand laminae are in places cut by Chondrites, visible on parting planes as dark clayey dots in light grey background. 
Interpretation. Silt/sand laminae were commonly observed in mudstones from the Zawiercie area. Their sharp boundaries, lenticular shape and irregular, probably erosive bases point to bedload transport in the form of thin starved ripples, whereas gradational tops observed in some laminae suggest deposition from suspension flows (Leonowicz, 2013). Based on these features, the silt/sand laminae are interpreted as the result of deposition by bottom flowing currents which carried suspended sediment and reworked the bottom deposit. In bioturbated mudstones, most of these structures were completely destroyed or took the form of parallel stripes, described above. Their preservation in some intervals, although to a limited extent, may be an effect of either a low bioturbation rate, or rapid event deposition of relatively thick portions of mud (cf. "smothered bottom" in Brett, 1983). In the latter case, only the upper part of the sediment is reworked, whereas the lower part remains undisturbed or only slightly bioturbated so that the original fabric is preserved.

BEDDING-PLANE ACCUMULATIONS OF SHELL DEBRIS

Observations. These are very thin, $<0.5 \mathrm{~mm}$ thick, horizontal accumulations of shell debris, consisting of fragmented shells of different bivalves, brachiopods and, in places, ammonites. They are well visible on parting planes, but are usually not discernible in cross-section.

Interpretation. Bedding-plane accumulations of shell debris were commonly observed in mudstones from the Zawiercie area. The convex-up orientation of bivalve shells, which is typical for material transported by traction (Middleton, 1967; Futterer, 1978) and the presence of genera, which do not occur in the host deposit, suggest that the material was at least partly supplied from other settings by bottom currents (Leonowicz, 2013). These currents supplied fragmented shells from the shallower zones of the basin and simultaneously reworked in situ the bottom sediment, leading to formation of thin shell lags. Thus, the shell debris accumulations, similarly as thin silt/sand laminae, are interpreted as high-energy event deposits.

SILT/SAND LENSES

Observations. These are small and medium, flat lenses composed of very fine sand, silt and, locally, shell debris. They are 1-25 mm thick and up to $60 \mathrm{~cm}$ long. However, the original thickness might be lower, as many of them are loaded. Some lenses reveal parallel and low-angle laminations, enhanced by thin clay partings. The latter are often strongly deformed by loading. Sporadically, small clay-chips were observed in the lower part of thicker structures (Fig. 6C). Lenses occur usually in series and accompany relatively thick accumulations of sand and shell debris, described below.

Interpretation. The silt/sand lenses are interpreted as a result of relatively abundant supply of sediment that was transported in the form of small ripplemarks by bottom currents carrying simultaneously fine particles in the suspension (cf. Leonowicz, 2013). Traction transport is supported by the lenticular shape, sharp boundaries and internal structure of lenses, including cross-lamination and parallel to low-angle inclined lamination. The grain-size gradation in the topmost parts of some lenses and the occurrence of graded rhythmites with sand lenses at the base - both features observed in laminated mudstones (Leonowicz, 2013) - indicate that ripple migration was followed by sedimentation of the suspension. The deposition of sand was preceded by the erosion of muddy bottom, as indicated by the occurrence of clay-chips in the bottom parts of some lenses. The good preservation of lenses in strongly bioturbated deposits may reflect either rapid sedimentation, or preference of burrowing animals not adapted for burrowing in the sandy substrate.

\section{SILT-, SAND- AND SHELL-DEBRIS-RICH LEVELS}

Observations. These horizons, up to $6 \mathrm{~cm}$ thick and at least $6 \mathrm{~m}$ wide, contain relatively large amounts of sand, silt and/or shell debris (Fig. 7). Coarse-grained material forms series of lenses, parallel stripes and thin layers, up to $2 \mathrm{~cm}$ thick, in which detrital quartz and bioclasts may be mixed together or form separate accumulations. Based on the composition, three types of coarse-grained levels may be distinguished:

1. Fine sand and silt accumulations - horizons of elongated lenses, stripes and thin layers, composed of quartz grains with subordinate admixture of small bivalve shells. Lenses are commonly loaded. Thin layers reveal fine parallel lamination enhanced by thin clay laminae (Fig. 7A). Despite partial bioturbation, lamination is usually well visible. In the lower parts of some accumulations, small clay-chips are present. Sand and silt-rich levels occur in the middle part of the Sowa + Gliński section, in the upper part of the Leszczyński section and in the lowermost part of the Gnaszyn section (Fig. 5).

2. Shell debris accumulations - horizons of elongated lenses and thin layers, composed of fragmented and comminuted shells of various bivalves, brachiopods and ammonites. Shell debris is mixed with well-preserved, although usually disarticulated valves of small bivalves (mainly nuculoids and astartids), which may be in a convex-up as well as in a convex-down position. In places, well-preserved small snails also occur. Wood fragments are also common in the shell debris accumulations. Coarse-grained horizons of this type occur in the middle part of the Sowa + Gliński section (Fig. 5).

3. Sand, silt and shell debris accumulations - horizons rich in shell debris and disarticulated valves of small bivalves, mixed with fine sand and silt. These levels are usually accompanied by series of sand/silt lenses and stripes, underlying and/or overlying the main horizon. One of such accumulations, in the Gnaszyn section, reveals indistinct cross-lamination, consisting of silt-, sand- and shell-debris-rich laminae alternating with thinner clay laminae (Fig. 7B). In the bottom part of this level, shells of small bivalves are in the convex-down position, whereas in the upper part they are in a preferred convex-up position (Fig. 7C). Sand, silt and shell debris accumulations occur in the upper half of the Sowa + Gliński section and in the lower part of the Gnaszyn section (Fig. 5).

Interpretation. Levels rich in sand, silt and shell debris record an exceptionally abundant supply of coarse-grained material combined with the reworking and winnowing of bottom sediment by bottom currents, which might be accompanied in some cases by wave stirring. The bedload transport is supported by the presence of sand/silt lenses within these horizons, discrete cross-lamination observed in the level from the Gnaszyn section and the convex-up position of bivalve shells (Futterer, 1978). Parallel lamination from sand/silt-rich levels could result from either simultaneous transport of silt, sand and flocculated clay as a bedload (Schieber et al., 2007; Schieber and Yawar, 2009), or deposition from suspension (Reineck and Singh, 1972). The preferential convex-down position of shells in some horizons is typical of settling from suspension (Futterer, 1978) and may record either rapid deposition from suspension (Middleton, 1967) or temporal resuspension by gentle wave stirring (Brett and Allison, 1998). The small clay-chips occurring in the bottom parts of some quartz-rich accumulations indicate that deposition of coarse-grained sediment was preceded by erosion of the bottom, caused probably by the same currents 

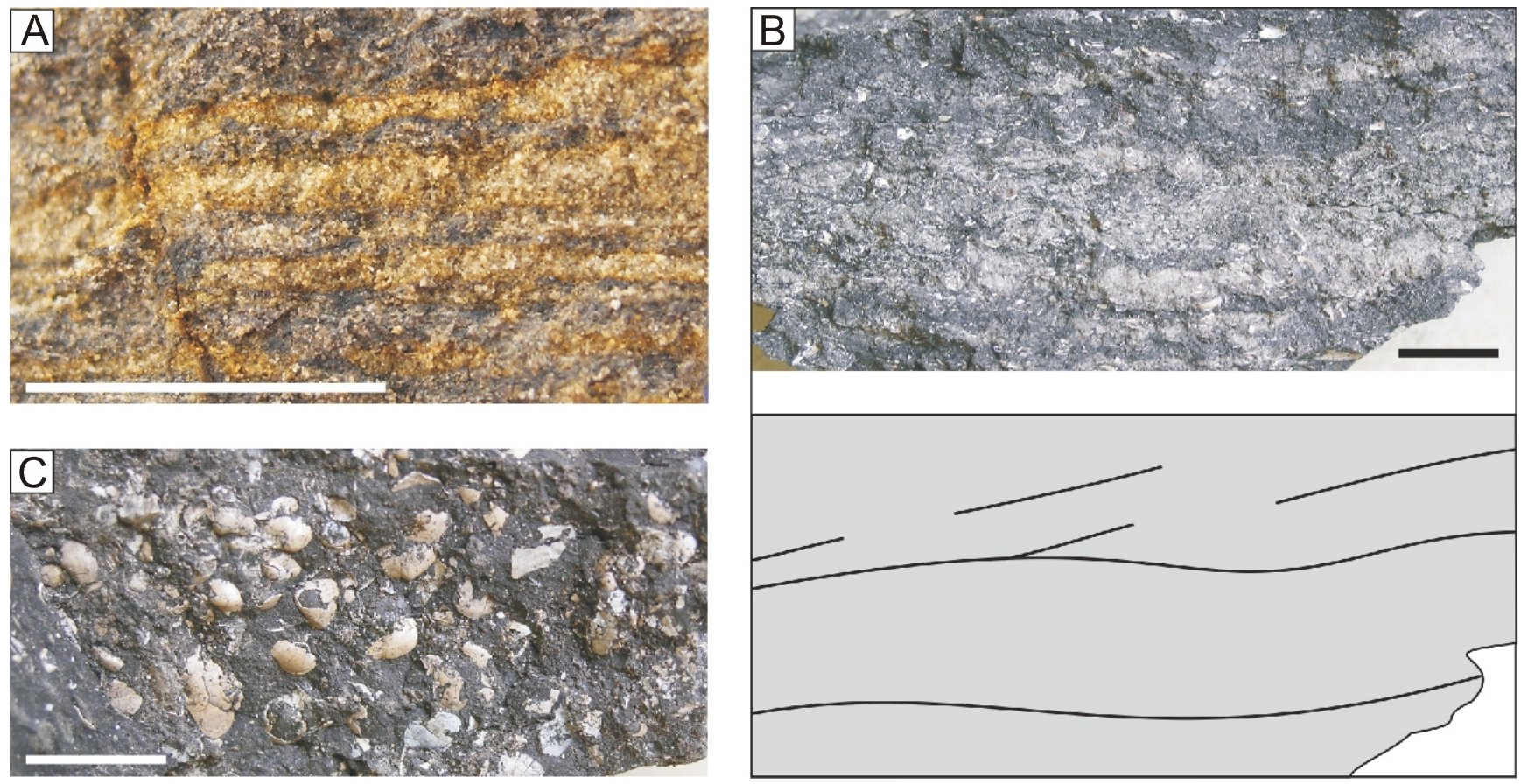

Fig. 7. Sedimentary structures from bioturbated mudstones of ore-bearing clays

A - fine sand and silt accumulation: fine parallel lamination consisting of alternating quartz and clay laminae; view perpendicular to the bedding; B - sand, silt and shell debris accumulation: in the upper part indistinct cross-lamination occur that consists of light grey coarse-grained laminae alternating with dark grey clay laminae alternating with dark grey clay laminae; the simplified scheme below the photo highlights lamination; view perpendicular to the bedding; $\mathbf{C}$ - the upper part of the accumulation shown on $\mathrm{B}$ : shells of small bivalves are in the preferred convex-up position; parting plane view; A - Leszczyński clay-pit, B, C - Gnaszyn clay-pit; scale bar is $1 \mathrm{~cm}$

that were responsible for sand supply. Rapid deposition of a relatively thick portion of sediment protected the silt, sand and shell debris horizons from complete bioturbation and resulted in their good preservation.

\section{EROSIONAL FEATURES}

Distinct erosional structures are scarce in the studied deposits. This results from monotonous development of mudstones and their strong bioturbation rather than the actual absence of erosion. The best evidence of significant winnowing and erosion in the bottom environment comes from the common occurrence of exhumed, deeply burrowing bivalves.

\section{EXHUMED BURROWING BIVALVES}

Observations. The studied deposits reveal rich benthic fauna, predominantly bivalves, representing different life habits (Pugaczewska, 1986; Kaim and Sztajner, 2012). The important components of the benthic association are deeply burrowing bivalves, represented by the genera Pleuromya, Pholadomya, Goniomya, Cercomya and Thracia. They usually occur in life position (Fig. 8A), although specimens lying flat on parting planes are also common (Fig. 8B). They are preserved as articulated specimens with closed valves, or in a "butterfly position" that points to the lack of or a very short transport. Exhumed deep-burrowing bivalves were observed throughout the entire succession, although their frequency changes in the profile (Fig. 5).

Exhumed shallow-burrowing bivalves are also common. Disarticulated shells of small bivalves, including nuculoids and astartids, occur in the shell debris accumulations discussed in the previous paragraph. The other example is semi-infaunal Pinna which, in some cases, sticks in the mud in life position, whereas in other places it lies flat on parting planes and is preserved as articulated or broken specimens.

Interpretation. The mode of the occurrence of infaunal bivalves suggests their in situ exhumation. As their shells are not associated with residual accumulations of sand, silt and shell debris, it seems that the sediment, in which they were originally buried, had to be removed by bottom flows, not simply resettled from the suspension. Considering that modern bivalves may burrow as deeply as $30 \mathrm{~cm}$ below the sea-floor (Stanley, 1970; Kondo, 1987), the depth of this erosion might be significant. The exhumed shallow-burrowing bivalves may record less intense erosion than that inferred from the deep-burrowing ones. However, the weak fragmentation of the Pinna specimens suggests a short-distance transport of their large shells, which indicates relatively high current strengths.

\section{EROSIONAL SURFACES}

Observations. The only distinct erosional surface was observed in the upper part of the Gnaszyn clay-pit (Fig. 5) at a level of few isolated sandy lenses, up to $6 \mathrm{~cm}$ thick, which represent the fill of small erosional scours (Fig. 8C). The sand lenses show horizontal lamination enhanced by thin clay partings.

Interpretation. The erosional surface is interpreted as a result of relatively strong erosion of the sea-floor (cf. Leonowicz, 2012). The scours were cut by channelised flow and subsequently filled with sand carried together with clay within the same flow. The sharp boundaries of the scours indicate cutting into the cohesive muddy bottom, thus the erosion was deeper than that inferred for the exhumed bivalves. 

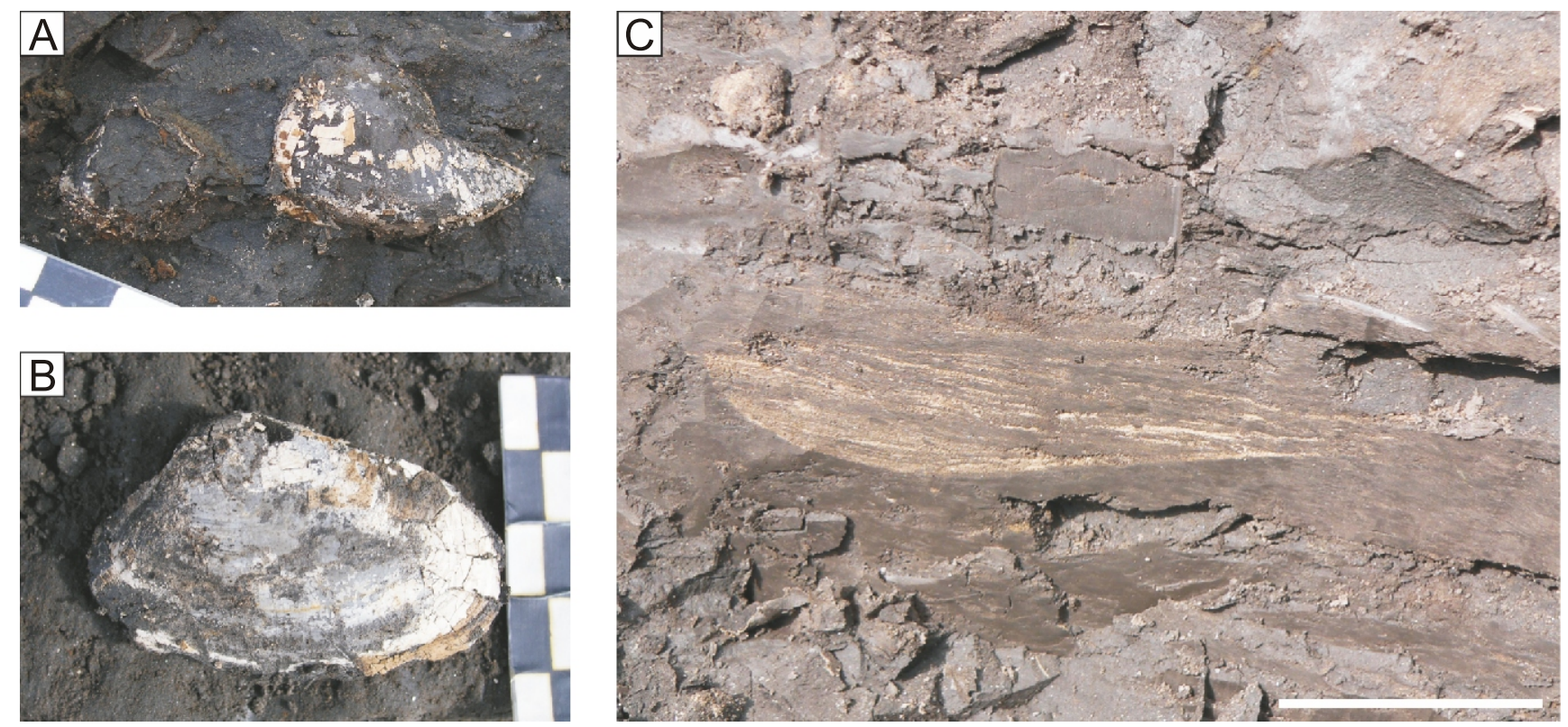

Fig. 8. Erosional features from bioturbated mudstones of ore-bearing clays

A, B - deeply burrowing bivalves: A - Pholadomya in life position; view perpendicular to the bedding planes; B - Pleuromya lying flat on a parting plane; $\mathbf{C}$ - erosional scour in mudstone, filled with fine-grained sand: horizontal lamination enhanced by thin clay coatings; view perpendicular to the bedding planes; A, C - Gnaszyn clay-pit, B - Anna clay-pit; A, B - scale bar is in centimetres, C - scale bar is $5 \mathrm{~cm}$ (photo C by A. Uchman)

\section{GRAIN-SIZE COMPOSITION}

Observations. Mudstones exposed in Częstochowa represent silty claystones and clayey siltstones locally containing significant admixtures of sand (Fig. 9). The content of clay varies from 23 to $71 \%$, silt - from 26 to $53 \%$ and sand - from 2.5 to $40 \%$. The vertical distribution of grain-size is presented on Figure 5. The highest proportion of clay occurs in the Upper Bajocian deposits (Alina section), where it does not fall $<50 \%$. The highest content of sand, $>30 \%$, is in the Middle and Upper Bathonian mudstones (upper parts of the Gnaszyn and Anna sections). The sand, silt and clay contents changes also laterally, however, the general trends in contemporaneous successions are consistent.

Interpretation. Sedimentological analysis of the ore-bearing mudstones from the Zawiercie region shows that most of the sediment was derived from the nearshore area by offshore currents (Leonowicz, 2013). In the deposits from Częstochowa, most of the primary sedimentary structures were obliterated by bioturbation, which led to mixing of sand and silt grains derived from the event laminae, with the clayey background. In this context, the clay-silt-sand proportions may be treated as a proxy for the original amount and thickness of event silt-sand laminae.

\section{SHELL DEBRIS CONTENT}

Observations. Shell debris is the common constituent of deposits studied. It consists of fragmented and comminuted shells of bivalves, brachiopods and ammonites. Apart from the bedding-plane accumulations, it is randomly dispersed throughout the mudstones, or concentrated in bioturbational structures. The amount of shell debris changes both vertically (Fig. 5) and laterally, and these changes show no clear correspondence to the fluctuating sand, silt and clay contents.
The middle and upper parts of the Sowa + Gliński section, in which bioclastic material is exceptionally abundant (Fig. 10A), deserve special attention. The rock consists of fragmented and comminuted shells of bivalves (i.a. common oysters) and rare ammonite fragments, all mixed with well-preserved, although disarticulated shells of small bivalves and crinoids. The latter are especially abundant in the uppermost part of the section (Figs. 5 and 10B). All this skeletal material is bound by muddy matrix. Shell debris tends to show a patchwork distribution,

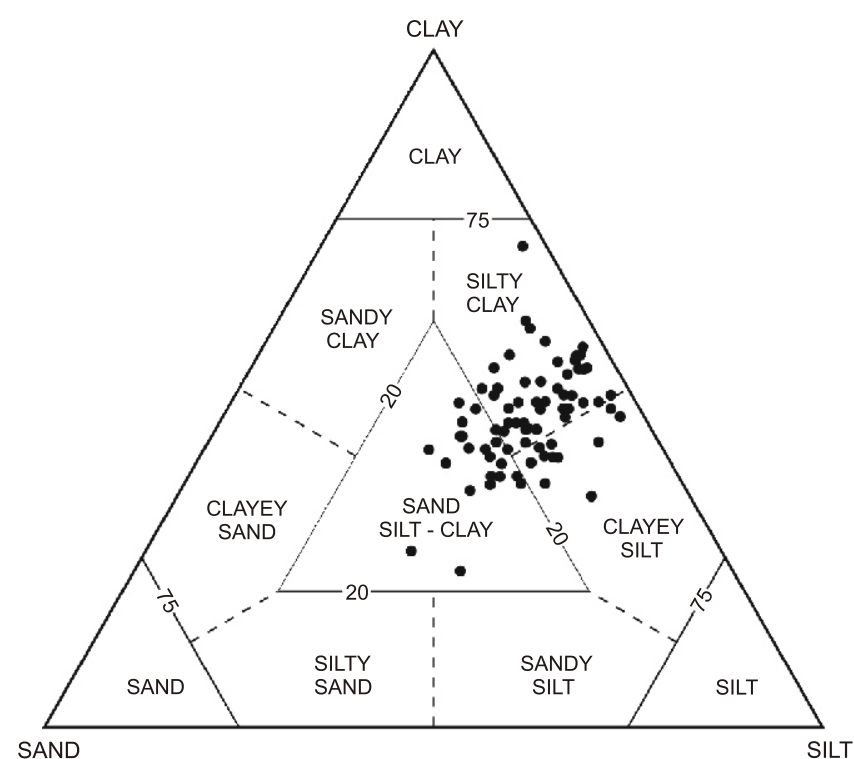

Fig. 9. Classification of ore-bearing mudstones from Częstochowa based on the clay, silt and sand contents

Nomenclature after Shepard (1954) 

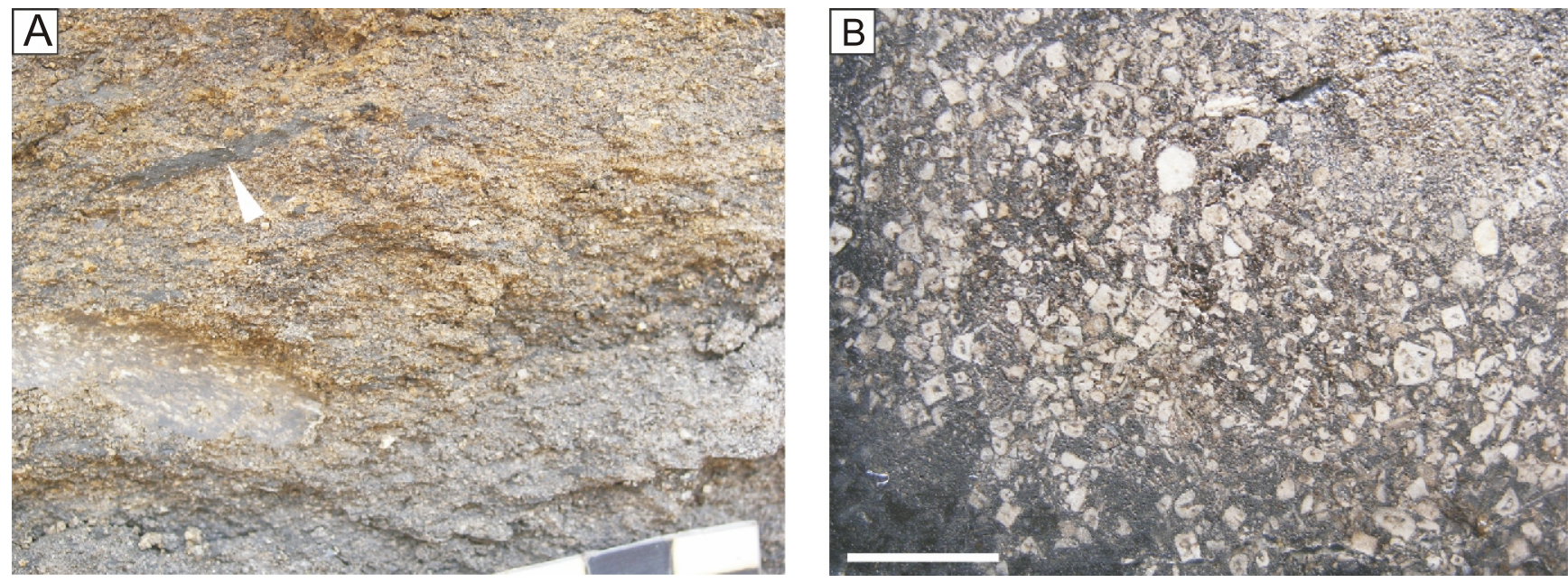

Fig. 10. Skeletal mudstones from the upper part of the Sowa + Gliński section

A - elongated clay-chip (arrow) within shell-debris-rich background; B - skeletal mudstone composed of abundant crinoids (cut surface of sample stabilized in polyester resin); A - scale bar is in centimetres, B - scale bar is $5 \mathrm{~mm}$

where zones rich in shell debris, up to several centimetres in thickness and a few metres in length, alternate with zones impoverished in skeletal material. In places, flat elongated clay-chips, up to $3 \mathrm{~cm}$ long and $4 \mathrm{~mm}$ thick, were observed (Fig. 10A). Skeletal mudstones are strongly disturbed by large biodeformational structures.

Interpretation. In laminated mudstones from the Zawiercie region, fragmented and comminuted shells are the common component of event laminae (Leonowicz, 2013). Thus, similarly to the grain-size composition, the shell debris content appears to approximate the amount of bioclastic material derived from shallower parts of the basin. However, unlike the detrital quartz grains, the source area of shell debris might be not only the shallow nearshore zone, but also intrabasinal elevations inhabited by benthic fauna. This diversification of source areas explains well the difference between fluctuation trends of shell debris content and the sand, silt and clay proportions.

\section{DISCUSSION}

\section{SEDIMENTARY ENVIRONMENT}

The similarity of sedimentary structures from the studied deposits to those described from the laminated mudstones in the Zawiercie area (Leonowicz, 2013) suggests common causative processes. These involved near-bed suspension currents, which reworked bottom sediment and transported the coarsest material as a bedload (Leonowicz, 2013). Deposition from suspension flows is supported by the presence of several features, such as graded laminae, laminae with sharp bottom and gradational upper contacts, fine parallel lamination and graded rhythmites. Evidence of traction transport includes flat silt-sand lenses showing cross-lamination and low-angle lamination, whereas the inversely graded laminae and sharpbounded silt-sand laminae reflect the current reworking of bottom sediment, linked with the winnowing of fine particles (Leonowicz, 2013). Such a mode of origin allows interpreting the coarse-grained laminae as event deposits, which record high-energy episodes interrupting quiet background sedimentation from suspension. These episodes might be linked with different processes, including storm-generated offshore cur- rents, turbidity currents and hyperpycnal flows maintained by waves and tides. The occurrence of turbidites (sensu Seilacher, 1991) in a shallow epicontinental sea is little probable, as their generation needs slopes steep enough to support autosuspension. They are common on continental slopes, but not on gently inclined shelf platforms. Thus, the origin of the coarse-grained laminae can be linked with storms and tides. Both can generate low-density suspension currents, which produce sequences of structures similar to those reported from fine-grained turbidites (e.g., Stow and Shanmugam, 1980; Hill, 1984; Stow and Piper, 1984; Pedersen, 1985; Myrow, 1992) and observed also in the deposits studied. If delivery of fine-grained sediment to the nearshore zone is high, storms and tides can also generate wave- and current-supported density flows, which carry suspended sediment in the form of fluid mud layer (Wright and Friedrichs, 2006). Such hyperpycnal layers are commonly observed in modern shelf environments and are the important mechanism of sediment redistribution from the inner shelf to the mid- and outer-shelf zones. According to Schieber and Yawar (2009), the lower portion of the fluid mud layer is transported as a bedload, whereas the upper one moves as a mud-rich suspension. The set of sedimentary structures from laminated mudstones in the Zawiercie area, especially cross-lamination observed in mud layers, indicates that at least part of the muddy sediment was transported by traction (Leonowicz, 2013). Thus, it is likely that besides the low-density suspension currents, such wave- and current-supported density flows might have played an important role in deposition of ore-bearing clays (cf. Leonowicz, 2013). Taking into account the random distribution of the coarse-grained event laminae in mudstones, it is more likely that their origin was linked with storm episodes rather than with tides, which are the cyclic phenomenon and would result in more regular alternations of fineand coarse-grained deposits. This, however, does not exclude the occurrence of tides in the basin and their contribution to the resuspension of sediment in the nearshore area.

Thicker accumulations of coarse-grained material, such as silt-, sand- and shell-debris-rich levels, not observed in the laminated mudstones, also reveal features suggesting their storm origin. Sedimentary structures, such as sand/silt lenses, discrete cross-lamination and the convex-up position of bivalve shells, point to deposition by bottom currents, preceded by ero- 
sion marked by clay-chips. The episodes of deposition might be followed, in some cases, by wave reworking, which is suggested by the convex-down position of shells. Alternatively, this feature might result from the rapid deposition from suspension, suggesting that bottom currents would have a complex character: in the lower part, the sediment would be transported as a bedload, in the upper one - as a suspension. The bimodal sorting of skeletal material points to its mixed origin, i.e. the derivation of comminuted shells from shallow parts of the basin and in situ reworking of well-preserved valves of small bivalves, which could be eventually transported for a short distance. Such composition of shell beds, combined with features recording currents activity, is characteristic of tempestite concentrations (Fürsich and Oschmann, 1993) and suggests that the levels rich in sand, silt and shell debris represent storm-event deposits. Similar interpretation was proposed by Leonowicz (2012) for the sand, silt and shell debris accumulations from the Gnaszyn clay-pit, and by Merta and Drewniak (1998) for the coarsegrained horizon from the Kawodrza clay-pit, interpreted as a storm lag deposit.

Skeletal mudstones from the Lower Bathonian convergens and macrescens subzones record the most abundant and prolonged supply of shell debris. They contain comminuted bioclastic material mixed with well-preserved bivalve shells. Such composition is characteristic of proximal tempestites and storm wave-base concentrations (Fürsich and Oschmann, 1993), reflecting derivation of fine shell debris from the zone above the fair-weather wave base combined with the reworking of bivalves at the depositional site. The high-energy conditions that accompanied deposition of skeletal mudstones are supported by the occurrence of clay-chips resulting from eroded semiconsolidated muddy bottom. Taking into account the relatively large thickness of skeletal mudstones $(>2 \mathrm{~m}$ ), these deposits may be interpreted as amalgamated storm beds that accumulated above the storm wave base. The highest energy conditions are recorded in the uppermost part of the section, containing skeletal mudstones with abundant crinoids. These deposits resulted from the prolonged reworking in a high-energy environment, which enriched the sediment with the most resistant elements and eliminated more fragile fragments (cf. Jennette and Pryor, 1993). It is possible that they accumulated close to, or above, the fair-weather wave base.

The common occurrence of storm-event deposits throughout the succession studied points to relatively high-energy conditions prevailing in the basin and suggests that the sedimentation was dominated by storms. The lack of parallel-ordered fabric in some intervals seems to be the result of intense bioturbation rather than its initial absence. Although storm processes affected the sea bottom throughout the time of deposition, their intensity was variable and resulted in the different thickness and types of event laminae. The thin silt/sand laminae, parallel stripes from clay-rich mudstones and bedding-plane accumulations of shell debris appear to record the weakest storm influence. More intense storm influence resulted in the deposition of silt/sand lenses and parallel stripes present in the shell debris- and sand-rich mudstones. Still stronger processes led to the accumulation of silt-, sand- and shell-debris-rich levels. The highest energy conditions were recorded by thick beds of skeletal mudstones, which record the periods when the wave base reached the bottom at depositional site.

The intensity of storm processes depends on atmospheric conditions and basin's depth. The other factors influencing composition of storm-event deposits are the distance of depositional site from the source of coarse-grained material derived mainly from the nearshore, as well as the initial composition of sediment accumulated in the shallow water zone. The latter may be influenced by climate, determining weathering type, which in turn affects the mineral composition and amount of material supplied by rivers. The Middle Jurassic climate in Europe was warm, humid and subjected to insignificant fluctuations during the Bajocian-Bathonian period (e.g., Hallam, 1985, 2001; for summary see Pieńkowski et al., 2008). Thus, the climatic factor is unlikely to have affected significantly the composition of event deposits, which would then reflect mainly the intensity of storm processes and the proximity of depositional site. According to these assumptions, intervals abounding in thick event beds would record deposition in shallow and relatively proximal locations, whereas those containing only the relicts of thin event lamination would reflect deeper, distal settings. In the bioturbated units of the ore-bearing clays, event laminae were destroyed by bioturbation and mixed with the background clay-rich deposit, but the original amount and thickness of them are now reflected by the grain size of mudstones. Generally, the high content of sand and silt in the deposits suggests relative proximity of the shoreline during the time of deposition. However, the varying sand, silt and clay ratio points to the fluctuation of the shoreline position and creates the basis for distinguishing seven transgressive-regressive cycles in the succession (Fig. 5). They are discussed in detail in the next section. It should be noted that the fluctuation of the shoreline position is not identified here with eustatic sea level changes. As many authors already emphasized, shoreline shifts can also result from a changing sediment supply and varying accommodation due to regional tectonic processes (e.g., Hallam, 1988; Posamentier et al., 1988).

The water depth may be determined only approximately because of the scarcity of well-preserved bathymetric indicators. The lack of structures of wave origin in most event deposits suggests that the bottom was prevalently below the storm wave base. The sediment resuspended by storm waves in the nearshore zone was redistributed offshore by gradient currents and finally deposited below the storm wave base. It might get above this level during exceptionally strong storms and during periods of significant shallowing of the basin, recorded by skeletal mudstones and horizons rich in silt, sand and shell debris. However, the bathymetric location of depositional setting below the storm wave base does not necessarily mean that the sea was deep. Studies of modern and ancient marine deposits have shown that in enclosed epeiric seas, the average effective storm wave base usually does not exceed $30 \pm 10 \mathrm{~m}$ and in shallow siliciclastic basins it may shallow even to $15 \pm 5 \mathrm{~m}$ (Immenhauser, 2009). Because in the Middle Jurassic the Silesian-Cracow region was situated in a marginal part of the Polish Basin, it may be inferred that the basin depth in the study area generally exceeded $20 \mathrm{~m}$, but periodically it might be shallower.

The important feature of the sedimentary environment of the ore-bearing clays was the occurrence of recurrent, short episodes of erosion. Merta and Drewniak (1998) and Zatoń et al. (2011) suggested that some siderite horizons might have developed along erosional surfaces. The present study shows that the erosion of bottom sediment was more common, although it affected mainly the uppermost, soft part of sediment column and hence, it is difficult to detect. The frequency of the occurrence of erosional surfaces, based mainly on the exhumed bivalves, may be significantly underestimated, as the total amount of benthos in the succession strongly depends on changing environmental conditions. Thus, many episodes of erosion might have not been recorded due to the scarcity of burrowing bivalves. Despite that, erosional surfaces occur commonly throughout the succession. This indicates that it is considerably incomplete, although deep erosion was rather rare. It 
is therefore likely that this part of the basin was situated prevalently in the bypass zone or, during the periods of shallowing, in a more proximal zone, from which sediment was periodically washed away during storms. Deposition took place mainly during waning stages of storms and in the fair-weather conditions. The variable intensity of erosional processes explains well the origin of intervals with common ammonites, suggesting a decrease in sedimentation rate. They probably reflect more intensive erosion and sediment winnowing, rather than decreased sediment supply.

The long-lasting periods, characterized by predominance of erosion, are recorded by horizons of hiatus concretions, reported by Zatoń et al. (2011) from six exposures of ore-bearing mudstones. Such concretion horizons have not been identified in the coeval strata studied here (Fig. 11). The only exception is the Gnaszyn clay-pit, in which Zatoń et al. (2011) observed few isolated concretions lying on the clay-pit floor. However, their stratigraphic position has not been established and no hiatus horizon has been found by the present author in this exposure. Thus, it seems that the rate of sedimentation was significantly decreased only in some parts of the basin and, as a result, the horizons of hiatus concretions are now of a local extent. According to Fürsich et al. (1992), the formation of this type of concretions requires simultaneous current reworking and reduced sedimentation rate. It is likely that the hiatus horizons from the Silesian-Cracow area could be linked with intrabasinal swells, where the sedimentation rate was lower and the erosion more intensive than in the intervening lows. The association of hiatus concretions with short-lived bottom elevations, forming due to the syndepositional tectonics, was reported by Wetzel and Allia (2000) from the Middle Jurassic of Switzerland. Differentiation of the sea-floor into swells and depressions, resulting from salt movements and syndepositional faults, is a phenomenon known from the epicontinental basin of Poland (e.g., Dadlez, 1994; Feldman-Olszewska, 1997). On a smaller scale, it was also postulated for the southern part of the Middle Jurassic Polish Basin, based on the differences in sediment thickness and the occurrence of neptunian dykes (Barski, 1999, 2012b).

\section{TRANSGRESSIVE-REGRESSIVE CYCLES AND DEPOSITIONAL HISTORY}

As was mentioned above, the interpretation of transgressive-regressive (T-R) cycles is based on the grain-size variation of mudstones and the contents of sedimentary structures (Fig. 5). Typical T-R cycle consists of a transgressive interval showing upward increase of clay and decrease in sand content, followed up by a regressive interval showing an upward opposite textural trend. It should be stressed that the absolute values of clay, silt and sand contents may vary laterally in coeval deposits in response to changing depositional conditions; however, vertical grain-size trends remain unchanged (Fig. 5; cf. Leonowicz, 2012). The contents of particular grain-size classes may also differ between equivalent parts of subsequent cycles (transgressive and regressive intervals) as a result of a different range of particular transgressions (cf. Feldman-Olszewska, 1998). Other sediment features, such as horizons of hiatus concretions, ammonite occurrences, erosional structures and coarse-grained levels, cannot be clearly linked in terms of frequency of occurrence with any specific parts of T-R cycles. For example, horizons of hiatus concretions often accompany progress and maximum of transgressions, but they can also occur in regressive intervals (Fig. 11). Silt-, sand- and shell-debris-rich levels may accompany late phases of regressions, but they can also occur in transgressive parts (Fig. 5).
The dating of cycles boundaries is based on high-resolution ammonite biostratigraphy (Matyja and Wierzbowski, 2000, 2003, 2006b; Fig. 5). The thicknesses of T-R cycles range from 9 to $22 \mathrm{~m}$, however, these values are only approximate, as most of cycles include unexposed intervals of unknown thicknesses (Fig. 5). There are also intervals lacking precise age determination that impedes correlation of sections and credible assessment of the cycle thickness (e.g., $\mathrm{TR}_{4}$ cycle in the Leszczyński and Gnaszyn sections).

The oldest deposits of the Middle Jurassic succession, exposed in the Częstochowa region, are of Late Bajocian age (parkinsoni chron; Matyja and Wierzbowski, 2000). They record a progress of transgression $T_{1}$, which is reflected by the upward increasing clay content (Fig. 5). According to FeldmanOlszewska (1998), the Polish Basin expanded at that time to the west and south-west and covered the vast area of the Polish Lowlands. At its maximum extension, the sea flooded almost the whole Wielkopolska Ridge. The progress of the transgression and turnaround to the following regression in the Silesian-Cracow region is accompanied by the formation of hiatus concretions, described by Zatoń et al. (2011) from the Wielun area (Fig. 11). The concretions probably record the period, in which the bottom was situated in the bypass zone. The decrease of sedimentation rate promoted also the growth of isolated oyster "reefs", reported by Matyja and Wierzbowski (2000) from deposits somewhat older than these exposed in the Alina clay-pit. The maximum of the transgression falls within the early bomfordi subchron (Fig. 5) and is followed by a short-lasting episode of the immigration of Tethyan ammonoids (Zatoń, 2011; Fig. 11). During the parkinsoni chron, strongly condensed shallow-marine deposits formed in the Zawiercie area (in Blanowice and probably in Ogrodzieniec - Zatoń et al., 2012; Fig. 11). This area was located in the southern periphery of the basin adjacent to the Małopolska Land (Dayczak-Calikowska and Moryc, 1988; Feldman-Olszewska, 1998).

Subsequent regression $R_{1}$ is recorded by a significant increase in the sand content (Fig. 5). According to Feldman-Olszewska (1998), the southwestern boundary of the Polish Basin retreated at that time to the north-east, exposing the Wielkopolska Ridge (Fig. 3A). The Silesian-Cracow region was then separated from the rest of the Polish Basin by a peninsular area of this ridge that continued further to the south-east as a submarine elevation. The maximum regression falls at the end of the bomfordi or the beginning of the convergens subchron (Fig. 5) and was associated with the beginning of sedimentation of shell-debris-rich deposits. The emergence of the Wielkopolska Ridge resulted in the development of an elongated nearshore shoal that, together with the coastal zone of the Małopolska Land, supplied biogenic material to the sedimentary basin. Simultaneously, the shallowing of the sea led to expansion of intrabasinal shallows, favouring the development of benthic community that also supplied bioclastic debris. The lowermost shell-debris-rich level occurring below siderite horizon D in the Sowa + Gliński section marks the lower boundary of the first skeletal mudstone complex. It is likely that this level represents a regressive lag, resulting from the reworking and winnowing of the bottom sediment, which approached close to the storm wave base. The overlying skeletal mudstones record deposition in relatively shallow, high energy conditions, probably within the range of storm waves.

A similar type of deposition continued also during the beginning of transgression $T_{2}$, recorded by the significant decrease in the sand content (Fig. 5). The expansion of the sea coincides with the deposition of condensed, oncoid-bearing calcareous deposits in the peripheral part of the basin (Ogrodzieniec near Zawiercie, Zatoń et al., 2012). Although biostratigraphic dating 


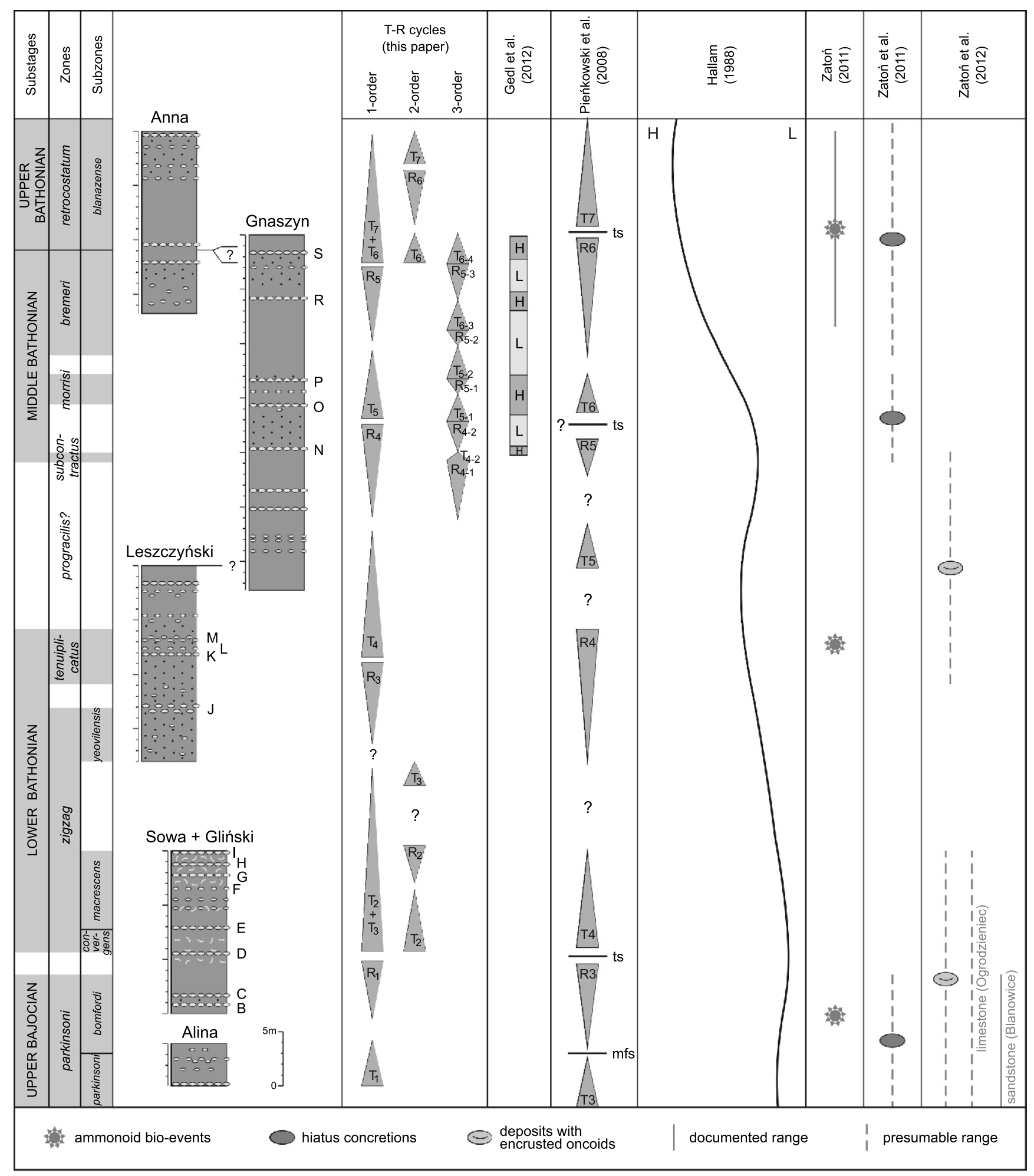

Fig. 11. Comparison of transgressive-regressive cycles proposed for the succession studied with Middle Jurassic cycles from central Poland (Pieńkowski et al., 2008) and the eustatic curve of Hallam (1988)

The scheme of sea level changes in Middle Bathonian (Gedl et al., 2012), the range of ammonoid bio-events (Zatoń, 2011) and the distribution of some characteristic Middle Jurassic deposits from Silesian-Cracow region (Zatoń et al., 2011, 2012); T - transgression, R regression, $\mathrm{mfs}$ - maximum flooding surface, ts -transgression surface, $\mathrm{H}$ - high sea level, $\mathrm{L}$ - low sea level; for explanation of lithological symbols see Figure 5 
of these rocks is not precise (parkinsoni-macrescens subchrons), Zatoń et al. (2012) suggest that they originated in the Early Bathonian. This age determination is consistent with the postulated maximum of the transgression that falls in the mid-macrescens subchron. The high content of shell debris dispersed in the mudstones and the occurrence of shell-debris-rich levels point to the continual supply of bioclastic material, linked with the proximity of shallow-water zone. It seems that the transgression led to the landward shift of shoreline, but not to a significant deepening in the offshore area. The source area of biogenic material was still a shallow-water zone adjoining the Małopolska Land as well as intrabasinal shallows. The flooding of the Wielkopolska Ridge, suggested by FeldmanOlszewska (1997), might even widen the area of shallow-water biogenic sedimentation, resulting in a plentiful supply of shell debris.

Regression $\mathrm{R}_{2}$ began in the mid-macrescens subchron and is recorded by the significant increase in sand content accompanied by especially abundant shell debris supply (Fig. 5). The increase in sand content suggests shortening of the distance from the shoreline, whereas the occurrence of skeletal mudstones rich in crinoids points to the shallow-water environment, in which the bottom was recurrently reworked by waves. A more detailed reconstruction of regression $R_{2}$ is impeded by the lack of exposures. However, it seems that this interval records the shallowest and the most proximal depositional environment in the entire succession studied.

The oldest deposits overlying this regressive interval are of the Early Bathonian age (yeovilensis subchron - Matyja and Wierzbowski, 2000) and may represent either the late phase of transgression $T_{3}$, the beginning of which falls on the unexposed part of the succession, or the early phase of regression $R_{3}$ (Fig. 5). The clay, silt and sand content in the lowermost part of the Leszczyński section is similar to that in the preceding regression $\mathrm{R}_{2}$ and points to a similar distance from the shoreline. The simultaneous decline of shell debris may reflect either an increase in fine-grained sediment supply, suppressing biogenic sedimentation, or the sinking of intrabasinal shoals. The first option is hardly probable. Increased sediment supply may be caused by either climate change or tectonic uplift in the hinterland. However, the climate during the studied period was relatively constant and the similarity of grain-size composition between the sediment in question and the underlying deposits rules out a tectonic trigger. Thus, the most likely explanation of the shell debris decline is the one assuming sinking of intrabasinal shoals. This sinking was likely caused by differential subsidence of the Silesian-Cracow region rather than the regional sea level rise in the whole basin and resulted in the local deepening of the bottom beyond the range of storm waves. By analogy to this event, the preceding period of bioclastic deposition during regression $R_{2}$ might be linked with a tectonic uplift in the source area (i.e. south part of the Wielkopolska Ridge) rather than with a basinwide sea level fall. Based on differences in sediment thicknesses, Feldman-Olszewska (1997) postulated tectonic activity in the southeastern part of the Wielkopolska Ridge during the Aalenian and Bajocian. The overall cessation of this activity in the Early Bathonian does not preclude prolonged local tectonic movements. Assuming such interpretation, the increase of sand content during regression $R_{2}$ would then result from the enhanced sediment supply caused by tectonic uplift of the south part of the Wielkopolska Ridge and not from the regional sea level fall in the entire basin. Thus, the $R_{2}$ interval may be interpreted as an event of limited extent, combining local tectonics and shoreline progradation that locally interrupted the progress of a regional transgression $\left(T_{2}+T_{3}\right.$; Fig. 11)
The increase in sand content taking place in the yeovilensis subzone (Fig. 5) records regression $R_{3}$. The late phase of this regression in the Częstochowa region is accompanied by frequent ammonite occurrences resulting from the decreased sedimentation rate. Sedimentation slowdown was caused most probably by the more intense scouring of the bottom not compensated by sediment supply that was less abundant at that time than in the early zigzag chron. The decreased (compared with regression $\mathrm{R}_{2}$ ) supply of terrestrial material can be linked to a diminishing of the source area, caused by the flooding of the Wielkopolska Ridge. The maximum of regression $R_{3}$ falls into the early tenuiplicatus chron (Fig. 5).

Transgression $T_{4}$ began in the tenuiplicatus zone (Fig. 5). The occurrence of several silt and sand-rich levels in this part of the succession indicates that, despite the transgression progress, the site's distance from the shoreline was still relatively short. The good preservation of these levels and other event laminae, which commonly occur in the uppermost part of the Leszczyński section, results from the incomplete bioturbation of mudstones by small and medium-sized animals. The early stage of transgression $\mathrm{T}_{4}$ coincides with the bio-event of proliferation of a dimorphic pair of the ammonoid Asphinctites tenuiplicatus (Fig. 11), described by Zaton (2011) who links this event with the eutrophication of sea water during transgression. According to Feldman-Olszewska (1998) and Pieńkowski et al. (2008), the sea expanded at that time far to the southwest and for the first time encroached onto the East European Platform. Dating of the transgression maximum is impossible at the moment. It falls to the uppermost part of the Leszczyński section and lowermost part of the Gnaszyn section, the age of which ranges from the upper tenuiplicatus to lower subcontractus zones, but has not been yet precisely determined. The correlation of these two sections, presented in Figure 5, is based on the grain-size trend and, as such, is provisional and has no stratigraphic value. The transgression maximum is probably recorded by the clayey-sandy deposits with oncoids, which originated in the Zawiercie region at the periphery of the basin (Zatoń et al., 2012; Fig. 11). However, the Bajocian-Lower Bathonian part of the succession from Zawiercie is strongly condensed and incomplete. The possible age of oncoids, inferred from the associated ammonite fauna, spans the tenuiplicatus to subcontractus zones and does not help to date the maximum of transgression.

The significant increase in sand content is a record of regression $\mathrm{R}_{4}$ (Fig. 5). The beginning of the regression is difficult to determine (see discussion above) and falls in the period from the tenuiplicatus to subcontractus chrons. Its maximum took place in the late subcontractus or early morrisi chron. The occurrence of silt, sand and shell-debris-rich levels below and above the $\mathrm{N}$ siderite horizon reflects increased supply of coarse material, accompanying the progress of the regression. Good preservation of these horizons results from the incomplete bioturbation of the mudstone, probably linked with episodic deposition of thick sediment blankets. The relatively thick coarse-grained levels, deposited in the late phase of the regression (above the $\mathrm{N}$ siderite horizon), may represent regressive lags accumulated as a result of prolonged reworking of the sediment by bottom currents and storm waves. The activity of the former is confirmed by indistinct cross-lamination observed in the lowest level (Figs. 5 and 7).

Transgression $T_{5}$ began in the late subcontractus or early morrisi chron and lasted until the early bremeri chron (Fig. 5). At that time, the continuous sedimentation of typical dark grey mudstones began in the Zawiercie area (Zatoń et al., 2012). It persisted until the end of the Bathonian and passed gradually into Callovian sandy-calcareous sedimentation (Barski et al., 
2004). The progress of transgression $T_{5}$ in the Silesian-Cracow region was accompanied by frequent ammonite occurrences (Fig. 5). These resulted from the more intensive scouring of the bottom caused possibly by its transition into the bypass zone. The reworking and erosion of the bottom sediment led also to the formation of hiatus concretions described by Zaton et al. (2011) from Bugaj near Częstochowa (Fig. 11). The age of these concretions was determined as the subcontractus or morrisi chron. However, considering that the erosion was much more intense in the morrisi chron, it is likely that hiatus horizons also formed at that time. The late phase of transgression $T_{5}$ and the early phase of next regression are characterized by the lack of detectable erosional surfaces (Fig. 5). It is possible that the growing distance from the shoreline led to the passage of the bottom from the bypass zone to more distal position, in which the sediment brought from the nearshore was deposited. The weakening of erosional processes and accumulation of the significant amount of sediment derived during storms resulted in increased sedimentation rate and more complete preservation of this part of the succession.

Regression $R_{5}$ began in the early bremeri chron and achieved its maximum during the late bremeri chron (Fig. 5). The progress of the regression as well as the beginning of the next transgression in the Silesian-Cracow region are accompanied by frequent intervals with common ammonites, which suggest that the sea bottom was subjected again to sediment bypass (Fig. 5). At that time, subsequent horizons of hiatus concretions formed (Zatoń et al., 2011; Fig. 11). Although they were found in other exposures (in the Zawiercie region) and cannot be precisely correlated with the sections studied, their age determination (bremeri and/or lower retrocostatum chrons) is consistent with the periods of decreased sedimentation rate. These periods are marked by common ammonite concentrations, which possibly reflect increased erosion. The bremeri chron is the time, when the long-lasting bio-event of proliferation and immigration of several ammonoid species began (Zatoń, 2011; Fig. 11). This event lasted until the mid-retrocostatum chron and may record the opening of new seaways during the extensive Late Bathonian transgression that enabled migration of ammonites (Zatoń, 2011). The beginning of ammonite migration during the period of regional regression suggests that the $R_{5}$ episode was, in fact, the time of sea level stillstand and associated shoreline progradation rather than the effect of regional sea level fall.

Transgression $T_{6}$ began in the late bremeri chron (Fig. 5) and its maximum falls into the early retrocostatum chron. It coincides with a mid-stage of the bio-event of ammonoid proliferation and immigration, as well as with the possible formation of hiatus concretions. Its early phase was also linked with the increased intensity of erosion that in places led to the deep scouring into the cohesive mud. The result of this erosion is the reduced sedimentation rate and condensation, marked by the common ammonite occurrences (Fig. 5).

The Gnaszyn succession, representing $R_{4}-T_{6}$ cycles, was recently studied by Gedl et al. (2012). These authors, based mainly on micropalaeontological and palynofacies analyses, noted fluctuations in nutrient supply and interpreted them in terms of sea level changes. They distinguished four transgressive-regressive cycles in the succession. The comparison of their interpretation with that proposed in the present paper (Fig. 11) shows that these short-lasting T-R cycles represent subordinate episodes, linked probably with differential sedimentation rate, which led to the shoreline fluctuation. Similar cycles may be also interpreted from the grain-size logs (Fig. 5), although boundaries of these cycles are slightly shifted in relation to those proposed by Gedl et al. (2012). The only distinct discrepancy in both interpretations concerns the interval located between siderite horizons $\mathrm{P}$ and $\mathrm{R}$, which is linked by Gedl et al. (2012) with regression, whereas the grain-size analysis points to transgression and a relatively distal environment. The explanation of this difference may be linked with the inferred mode of deposition. The interpretation of Gedl et al. (2012) is based on the assumption that the terrigenous material was deposited from suspension and supplied directly from the land to the depositional setting. The sedimentological analysis shows, however, that most of the sediment was redistributed during storms from the initial place of deposition by offshore-directed currents. As mentioned above, the interval in question records probably the time, in which the bottom switched from bypass to accumulative mode. Thus, the features considered to be typical of proximal settings, such as the prevalence of terrigenous elements in palynofacies composition, opportunistic planktonic assemblages and the prevalence of sporomorphs of the Lowland Ecogroup (Gedl et al., 2012), might be inherited from the initial place of deposition, from which the sediment was brought in Pieńkowski (2004) and Pieńkowski and Waksmundzka (2009) reported a similar phenomenon, called "palynofacies inversion - type 2", from Lower Jurassic deposits of Poland. Moreover, the increased rate of deposition and associated higher influx of organic particles, leading to the oxygen depletion within the bottom sediment, need not be the result of a proximal location, but may reflect the decreased intensity of erosion in more distal sites.

Regression $\mathrm{R}_{6}$ began in the early retrocostatum chron and reached its maximum in the $\mathrm{mid} /$ late retrocostatum chron (Fig. 5). It is recorded by the significant increase in the sand content (up to $40 \%$ ). The retrocostatum chron coincides also with the late stage of the bio-event of ammonoid proliferation and immigration (Zatoń, 2011; Fig. 11), which points to the expansion of the sea. All this evidence suggests that it was a period of fast shoreline progradation that occurred locally in the Silesian-Cracow region during the stillstand conditions. Consequently, the last transgression $T_{7}$, recorded by the gradual increase in clay content (Fig. 5), may be interpreted as a continuation of the earlier transgression $T_{6}$. In the early phase of regression $R_{6}$, erosional processes, marked by exhumed bivalves, were not common. In the late phase, they were much more abundant and led to the decrease in sedimentation rate, recorded by common ammonites. It is possible, although not proved, that hiatus concretions also formed at that time (Zaton et al., 2011).

COMPARISON WITH T-R CYCLES IN CENTRAL POLAND AND EUSTATIC SEA LEVEL CHANGES

To verify whether the T-R cycles from the Częstochowa region record fluctuations of the regional sea level in the entire Polish Basin or reflect some local processes, they were correlated (Fig. 11) with cycles distinguished in the succession from central Poland (Pieńkowski et al., 2008). The correlation is based on ammonite and dinoflagellate cyst biostratigraphy (Feldman-Olszewska, 1997; Matyja and Wierzbowski, 2000, 2003, 2006b; Barski, 2007, 2008, 2012a; Pieńkowski et al., 2008), however, different precision of dating of deposits studied in outcrops (Częstochowa) and boreholes (central Poland) as well as incompleteness of the succession from Częstochowa make this correlation approximate.

Cycle $\mathrm{TR}_{1}$ (parkinsoni-bomfordi/early convergens? subchrons) correlates well with cycle TR3 from central Poland, which began in the garantiana chron and lasted until the early convergens subchron (Pieńkowski et al., 2008). Similarly, the 
early phase of transgression $\mathrm{T}_{2+3}$, which began in the convergens subchron corresponds to transgression T4 that commenced in the mid-convergens subchron and reached its maximum at the end of the macrescens subchron (Pieńkowski et al., 2008). The correlation of the late phase of transgression $\mathrm{T}_{2+3}$ is impeded by the lack of exposures in the Częstochowa region, which makes impossible credible dating of its maximum. However, it cannot be excluded that it coincides with the maximum of transgression T4 distinguished by Pieńkowski et al. (2008). Regression $R_{2}$, recording the shallowest conditions in the entire succession studied, does not manifest itself in the succession from central Poland and was likely local.

Regression $\mathrm{R}_{3}$ (yeovilensis-early tenuiplicatus subchrons) correlates approximately with regression R4 in central Poland, which began in the early yeovilensis subchron and lasted most probably until the end of the tenuiplicatus chron (Pieńkowski et al., 2008). The shift of the regression maximum between these two regions may arise from the imprecise dating of deposits from central Poland, because of the scarcity of ammonite fauna in this part of the succession. Thus, it cannot be excluded that the late phases of regressions $R_{3}$ and R4 coincide.

For the same reason, the age determination of the next cycle TR5 in central Poland is uncertain. Pieńkowski et al. (2008) suggest that the transgressive phase falls within the progracilis chron and the regressive phase - in the subcontractus chron, but this statement is not sufficiently supported by ammonites. In the Częstochowa region, deposits dated at the progracilis zone have not been documented yet, although it is likely that they occur in the Leszczyński and Gnaszyn sections, corresponding to the maximum of transgression $\mathrm{T}_{4}$ and the beginning of regression $\mathrm{R}_{4}$. Similarly, the occurrence of the subcontractus zone was confirmed only in a thin interval of the Gnaszyn section, representing the middle part of regression $R_{4}$ (Figs. 5 and 11). Thus, at the moment, the credible correlation of cycle $\mathrm{TR}_{4}$ with the scheme from central Poland is not possible, although it is probable that this cycle correlates with cycle TR5 distinguished by Pieńkowski et al. (2008).

Cycle $\mathrm{TR}_{5}$ (subcontractus/morrisi?-late bremeri chrons) correlates approximately with cycle TR6 in central Poland (morrisi - early retrocostatum chrons), although the maximum of transgression seems to be shifted in these two successions. The reason of this discrepancy may be uncertainty in dating of the transgression maximum in the succession from central Poland, which is not sufficiently supported by ammonite fauna (Pieńkowski et al., 2008). Thus, it cannot be excluded that transgressions $T_{5}$ and $T 6$ coincide. Regression $R_{5}$ reached its maximum slightly earlier than regression $\mathrm{R} 6$, which probably results from local processes, e.g., different sedimentation rates. The middle and late phases of transgression $\mathrm{T}_{6+7}$ (late bremeri -retrocostatum chrons) correlates well with transgression T7 that lasted throughout the retrocostatum chron (Pieńkowski et al., 2008). Regression $R_{6}$ does not manifest itself in the succession from central Poland, which supports its local character.

The cycles distinguished in the succession from Częstochowa correlate partly also with the eustatic curve of Hallam (1988). Cycle TR 1 coincides well with a distinct sea level rise on this curve followed by a subordinate sea level fall (Fig. 11). The following prolonged sea level rise on the Hallam's curve corresponds to the series of subsequent transgressions $\mathrm{T}_{2+3}$ and $\mathrm{T}_{4}$ in the Częstochowa region. Intervening regressions $R_{2}$ and $R_{3}$ do not show up on the eustatic curve, which supports their local $\left(R_{2}\right)$ and regional $\left(R_{3}\right)$ character. Regression $R_{4}$ fits into a distinct sea level fall on the Hallam's curve and the next transgressions $T_{5}$ and $T_{6+7}$ correlate with a long-lasting sea level rise. Regressions $R_{5}$ and $R_{6}$ had a local or regional extent and are not marked on the eustatic curve. Hallam (2001) suggested that the Jurassic period experienced a gradual rise of sea level interrupted by stillstands rather than eustatic falls. According to him, the Late Bajocian-Late Bathonian parts of the curve reflect a distinct eustatic rise that began in the Late Bajocian and was interrupted by regressions of only regional extent, related to tectonic events. This would mean that none of the $T-R$ cycles distinguished in the present study resulted from eustatic sea level changes, but were the events of regional or local extent, which recorded relative sea level changes in the Polish Basin or in the Silesian-Cracow region only.

\section{CONCLUSIONS}

The detailed examination of the ore-bearing mudstones from the Częstochowa region revealed common relics of sedimentary structures, most of which record storm stirring and event sedimentation. It documents periodic high-energy conditions of mud deposition and indicates that the erosional events exerted a significant impact on the sedimentation rate.

The mudstones were deposited in the marginal part of the epicontinental Polish Basin. The sea bottom was prevalently below the storm wave base. However, the storm wave base reached the sea-floor during considerable shallowing of the basin in the early zigzag chron as well as during exceptionally strong storms. The shallowest and highest energy conditions occurred in the late macrescens subchron, when the bottom was close to, or above the fair-weather wave base. The estimated depth of the sea did not exceed several tens of metres and in some periods of time it could be even $<20 \mathrm{~m}$.

The significant part of accumulated sediment was derived from the nearshore zone and intrabasinal shallows by storm-generated bottom currents that simultaneously reworked and eroded the muddy bottom. Erosional surfaces are common in the entire succession, although the erosion affected mainly the uppermost, soft part of sediment column. Periods of the increased intensity of erosional processes are recorded by intervals with common ammonites and horizons with hiatus concretions. The latter formed in the bypass zone, rather than in the shallow subtidal area, and were probably linked to sea-floor elevations generated by differential subsidence.

The thickness and composition of event-storm deposits depended on the intensity of storms and on the distance of depositional site from the shoreline. The analysis of sand, silt and clay proportions, which approximates the original amount of event laminae, allowed distinguishing seven transgressive-regressive cycles within the succession studied. Most of these T-R cycles correlate roughly with the cycles distinguished by Pieńkowski et al. (2008) in the succession from central Poland, although the stratigraphic position of cycle boundaries and transgression maxima are usually slightly shifted between these schemes. Based on this correlation, it is suggested that cycles $\mathrm{TR}_{1}, \mathrm{TR}_{2+3}, \mathrm{TR}_{5}$ and $\mathrm{TR}_{6+7}$ reflect relative sea level changes in the whole Polish Basin. Regressions $R_{2}$ and $R_{6}$ record smaller-scale events generated by local tectonic activity and autocyclic shoreline progradation. Cycle $\mathrm{TR}_{4}$ cannot be reliably correlated with the cycles from central Poland due to the lack of precise biostratigraphical control. Besides geological constraints, the varying precision of age determination and discontinuous core and outcrop record may also have contributed to the observed mismatch between the TR cycles across the entire Polish Basin. 
Acknowledgements. The authoress would like to thank two anonymous reviewers and S. Porębski, the journal editor, for their constructive comments, corrections and useful remarks, which improved the final version of the manuscript. The managements of brickyards: "Alina", "Sowa", CEGBUD Gliński,
Leszczyński-Wytrzymały, "Anna" and Wienerberger Gnaszyn in Częstochowa are thanked for providing access to their workings. The research was financed by the Institute of Geology, University of Warsaw (BST grants No. 163702 and No. 166 902).

\section{REFERENCES}

Barski, M., 1999. Dinocyst stratigraphy of the Jurassic black clays from Holy Cross Mts area (Central Poland) (in Polish with English summary). Przegląd Geologiczny, 47: 718-722.

Barski, M., 2007. Stratygrafia jury środkowej na podstawie cyst Dinoflagellata (in Polish). Profile Głębokich Otworów Wiertniczych Państwowego Instytutu Geologicznego, 117: 67-71.

Barski, M., 2008. Wyniki badań stratygraficznych w otworze wiertniczym Brześć Kujawski IG 2 na podstawie organicznych cyst Dinoflagellata (in Polish). Profile Głębokich Otworów Wiertniczych Państwowego Instytutu Geologicznego, 125: 161-165.

Barski, M., 2012a. Wyniki badań stratygraficznych w otworach wiertniczych Wojszyce IG 3 i IG 4 na podstawie organicznych cyst Dinoflagellata (in Polish). Profile Głębokich Otworów Wiertniczych Państwowego Instytutu Geologicznego, 137: 142-149.

Barski, M., 2012b. Dinoflagellate cysts from neptunian dykes in the Middle Jurassic of Poland - a stratigraphical approach. Review of Palaeobotany and Palynology, 169: 38-47.

Barski, M., Dembicz, K., Praszkier, T., 2004. Biostratigraphy and the Mid-Jurassic environment from the Ogrodzieniec quarry (in Polish with English summary). Tomy Jurajskie, 2: 61-68.

Brett, C.E., 1983. Sedimentology, facies and depositional environments of the Rochester Shale (Silurian; Wenlokian) in western New York and Ontario. Journal of Sedimentary Petrology, 53: 947-971.

Brett, C.E., Allison, P.A., 1998. Paleontological approaches to the environmental interpretation of marine mudrocks. In: Shales and mudstones, 1: Basin studies, sedimentology and paleontology (eds. J. Schieber, W. Zimmerle and P.S. Sethi): 301-349. Schweizerbart'sche Verlagsbuchhandlung, Stuttgart.

Dadlez, R., 1994. Strike-slip movements in the Polish Lowlands. Geological Quarterly, 38 (2): 307-318.

Dadlez, R., 2003. Mesozoic thickness pattern in the Mid-Polish Trough. Geological Quarterly, 47 (3): 223-240.

Dadlez, R., Marek, S., Pokorski, J., eds, 2000. Geological map of Poland without Cainozoic deposits, 1:1 000 000. Państwowy Instytut Geologiczny, Warszawa.

Dadlez, R., Narkiewicz, M., Stephenson, R.A., Visser, M.T.M., Wees, J-D., van, 1995. Tectonic evolution of the Mid-Polish Trough: modelling implications and significance for central European geology. Tectonophysics, 252: 179-195.

Dayczak-Calikowska, K., 1997. Jura środkowa: sedymentacja, paleogeografia i paleo tektonika (in Polish). Prace Państwowego Instytutu Geologicznego, 153: 269-282.

Dayczak-Calikowska, K., Kopik, J., 1973. Jura środkowa (in Polish). In: Budowa geologiczna Polski, vol. 1 Stratygrafia, cz. 2 Mesozoic: 237-324. Wyd. Geol., Warszawa.

Dayczak-Calikowska, K., Moryc, W., 1988. Evolution of sedimentary basin and palaeotectonics of the Middle Jurassic in Poland (in Polish with English summary). Kwartalnik Geologiczny, 32 (1): 117-136.

Feldman-Olszewska, A., 1997. Depositional architecture of the Polish epicontinental Middle Jurassic basin. Geological Quarterly, 41 (4): 491-508.

Feldman-Olszewska, A., 1998. Palaeogeographical maps of Middle Jurassic, pl. 36-47. In: Palaeogeographical Atlas of the
Epicontinental Permian and Mesozoic in Poland (eds. R. Dadlez, S. Marek and J. Pokorski). Państwowy Instytut Geologiczny, Warszawa.

Futterer, E., 1978. Hydrodynamic behaviour of biogenic particles. Neues Jahrbuch für Geologie und Paläontologie Abhandlungen, 157: $37-42$.

Fürsich, F.T., Oschmann, W., Singh, I.B., Jaitly, A.K., 1992 Hardgrounds, reworked concretion levels and condensed horizons in the Jurassic of western India: their significance for basin analysis. Journal of the Geological Society, 149: 313-331.

Fürsich, F.T., Oschmann, W., 1993. Shell beds as tools in basin analysis: the Jurassic of Kachchh, western India. Journal of the Geological Society, 150: 169-185.

Garbowska, J., Łącka, B., Pazdro, O., 1978. Interrelation between microfauna and nature of Dogger deposits of the Częstochowa Jura (Poland). Acta Geologica Polonica, 23: 89-105.

Gedl, P., Boczarowski, A., Kaim, A., Kędzierski, M., Leonowicz, P., Smoleń, J., Szczepanik, P., Witkowska, M., 2006a. Field Trip B1 - Biostratigraphical framework from Bajocian to Oxfordian. Stop B1.5 - Sowa's and Gliński's clay pits (uppermost Bajocian - lowermost Bathonian). Lithology, fossil assemblages and palaeoenvironment. In: Jurassic of Poland and adjacent Slovakian Carpathians (eds. A. Wierzbowski et al.): 151-152. Field trip guidebook. 7th International Congress on the Jurassic System, 6-18 September 2006, Kraków, Poland.

Gedl, P., Boczarowski, A., Kaim, A., Kędzierski, M., Leonowicz, P., Smoleń, J., Szczepanik, P., Witkowska, M., 2006b. Field Trip B1 - Biostratigraphical framework from Bajocian to Oxfordian. Stop B1.6 - Leszczyński's clay pit (Lower Bathonian). Lithology, fossil assemblages and palaeoenvironment. In: Jurassic of Poland and adjacent Slovakian Carpathians (eds. A. Wierzbowski et al.): 153-154. Field trip guidebook. 7th International Congress on the Jurassic System, 6-18 September 2006, Kraków, Poland.

Gedl, P., Boczarowski, A., Dudek, T., Kaim, A., Kędzierski, M., Leonowicz, P., Smoleń, J., Szczepanik, P., Witkowska, M., Ziaja, J., 2006c. Field Trip B1 - Biostratigraphical framework from Bajocian to Oxfordian. Stop B1.7 - Gnaszyn clay pit (Middle Bathonian - lowermost Upper Bathonian). Lithology, fossil assemblages and palaeoenvironment. In: Jurassic of Poland and adjacent Slovakian Carpathians (eds. A. Wierzbowski et al.): 155-156. Field trip guidebook. 7 th International Congress on the Jurassic System, 6-18 September 2006, Kraków, Poland.

Gedl, P., Kaim, A., Leonowicz, P., Boczarowski, A., Dudek, T., Kędzierski, M., Rees, J., Smoleń, J., Szczepanik, P., Sztajner, P., Witkowska, M., Ziaja, J., 2012. Palaeoenvironmental reconstruction of Bathonian (Middle Jurassic) ore-bearing clays at Gnaszyn, Kraków-Silesia Homocline, Poland. Acta Geologica Polonica, 62: 463-484.

Hallam, A., 1985. A review of Mesozoic climates. Journal of Geological Society, 142: 433-445.

Hallam, A., 1988. A reevaluation of Jurassic eustasy in the light of new data and the revised Exxon curve. SEPM Special Publication, 42: 261-273.

Hallam, A., 2001. A review of the broad pattern of Jurassic sea-level changes and their possible causes in the light of current knowl- 
edge. Palaeogeography, Palaeoclimatology, Palaeoecology, 167: 23-37.

Hill, P.R., 1984. Facies and sequence analysis of Nova Scotian Slope muds: turbidite vs "hemipelagic" deposition. Geological Society Special Publications, 15: 311-318

Immenhauser, A., 2009. Estimating palaeo-water depth from the physical rock record. Earth-Science Reviews, 96: 107-139.

Jennette, D.C., Pryor, W.A., 1993. Cyclic alternation and distal storm facies: Kope and Fairview Formations (Upper Ordovician), Ohio and Kentucky. Journal of Sedimentary Petrology, 63: 183-203.

Kaim, A., Sztajner, P., 2012. Faunal dynamics of bivalves and scaphopods in the Bathonian (Middle Jurassic) ore-bearing clays at Gnaszyn, Kraków-Silesia Homocline, Poland. Acta Geologica Polonica, 62: 381-395.

Kondo, Y., 1987. Burrowing depth of infaunal bivalves - observation of living species and its relation to shell morphology. Transactions and Proceedings of the Palaeontological Society of Japan, 148: 306-323.

Kopik, J., 1997. Jura środkowa: formalne i nieformalne jednostki litostratygraficzne - Jura Polska (in Polish). Prace Państwowego Instytutu Geologicznego, 153: 263-264.

Kopik, J., 1998. Lower and Middle Jurassic of the north-eastern margin of the Upper Silesian Coal Basin (in Polish with English summary). Biuletyn Państwowego Instytutu Geologicznego, 378: 67-129.

Kutek, J., 1994. Jurassic tectonic events in south-eastern cratonic Poland. Acta Geologica Polonica, 44: 167-221.

Leonowicz, P., 2012. Sedimentology and ichnology of Bathonian (Middle Jurassic) ore-bearing clays at Gnaszyn, Kraków-Silesia Homocline, Poland. Acta Geologica Polonica, 62: 281-296.

Leonowicz, P., 2013. The significance of mudstone fabric combined with palaeoecological evidence in determining sedimentary processes - an example from the Middle Jurassic of southern Poland. Geological Quarterly, 57 (2): 243-260.

Lewandowski, J., 1986. Szkic geologiczny odkryty, 1:100 000 (in Polish). In: Objaśnienia do Szczegółowej Mapy Geologicznej Polski 1:50 000, arkusz Częstochowa (eds. W. Bardziński et al.). Wyd. Geol., Warszawa.

Matyja, B.A., Wierzbowski, A., 2000. Ammonites and stratigraphy of the uppermost Bajocian and Lower Bathonian between Częstochowa and Wieluń, Central Poland. Acta Geologica Polonica, 50: 191-209.

Matyja, B.A., Wierzbowski, A., 2003. Ammonite stratigraphy of the Częstochowa ore bearing clay formation (Uppermost Bajocian-Upper Bathonian) in the clay-pit at Częstochowa (in Polish). Tomy Jurajskie, 1: 3-6.

Matyja, B.A., Wierzbowski, A., 2006a. European Platform. Introduction. Middle and Upper Jurassic. In: Jurassic of Poland and adjacent Slovakian Carpathians (eds. A. Wierzbowski et al.): 130-131. Field trip guidebook. 7th International Congress on the Jurassic System, 6-18 September 2006, Kraków, Poland.

Matyja, B.A., Wierzbowski, A., 2006b. Field Trip B1 Biostratigraphical framework from Bajocian to Oxfordian. Stop B1.5 - Sowa's and Gliński's clay pits (uppermost Bajocian lowermost Bathonian). Ammonite biostratigraphy. In: Jurassic of Poland and adjacent Slovakian Carpathians (eds. A. Wierzbowski et al.): 149-151. Field trip guidebook. 7th International Congress on the Jurassic System, 6-18 September 2006, Kraków, Poland.

McManus, J., 1988. Grain size determination and interpretation. In: Techniques in Sedimentology (ed. M.E. Tucker): 63-85. Blackwell Science, Oxford, London, Edinburgh, Cambridge, Carlton.

Merta, T., Drewniak, A., 1998. Lithology and depositional environment of the Bathonian clays. In: Mellem-Øvre Jura i Polen. EEP-1995 projekt: Det polske Mellem-Øvre Epikratoniske Bassin, Stratigrafi, Facies og Bassin Historie. Program Østeuropa. Danmarks og Grønlands Geologiske Undersøgelse Rapport 1998/14 (eds. N.E. Poulsen et al.): 25-41.
Middleton, G.V. 1967. The orientation of concavo-convex particles deposited from experimental turbidity currents. Journal of Sedimentary Petrology, 37: 229-232.

Myrow, P.M., 1992. Bypass-zone tempestite facies model and proximality trends for an ancient muddy shoreline and shelf. Journal of Sedimentary Petrology, 62: 99-115.

O'Brien, N.R., 1996. Shale lamination and sedimentary processes. Geological Society Special Publications, 116: 23-36.

Pedersen, G.K., 1985. Thin, fine-grained storm layers in a muddy shelf sequence: an example from the Lower Jurassic in the Stenlille 1 well, Denmark. Journal of the Geological Society, 142: 357-374.

Pemberton, S.G., MacEachern, J.A., Gingras, M.K, Saunders, T.D.A, 2008. Biogenic chaos: Cryptobioturbation and the work of sedimentologically friendly organisms. Palaeogeography Palaeoclimatology, Palaeoecology, 270: 273-279.

Pieńkowski, G., 2004. The epicontinental Lower Jurassic of Poland. Polish Geological Institute Special Papers, 12: 1-154.

Pieńkowski, G., Waksmundzka, M., 2009. Palynofacies in Lower Jurassic epicontinental deposits of Poland: tool to interpret sedimentary environments. Episodes, 32: 21-32.

Pieńkowski, G., Schudack, M.E., eds., Bosák, P., Enay, R., Feldman-Olszewska, A., Golonka, J, Gutowski, J., Herngreen, G.F.W., Jordan, P., Krobicki, M., Lathuiliere, B., Leinfelder, R.R., Michalík, J., Mönnig, E., Noe-Nygaard, N., Pálfy, J., Pint, A., Rasser, M.W., Reisdorf, A.G., Schmid, D.U., Schweigert, G., Surlyk, F., Wetzel, A., Wong, T.E., 2008. Jurassic. In: The Geology of Central Europe. Volume 2: Mesozoic and Cenozoic (ed. T. McCann): 823-922. Geological Society of London.

Posamentier, H.W., Jervey, M.T., Vail, P.R., 1988. Eustatic controls on clastic deposition I - conceptual framework. SEPM Special Publication, 42: 109-124.

Pugaczewska, H., 1986. Bivalvia of the Polish Middle Jurassic and remarks on their paleoecology. Acta Palaeontologica Polonica, 31: $27-83$

Reineck, H.E., Singh, I.B., 1972. Genesis of laminated sand and graded rhythmites in storm-sand layers of shelf mud. Sedimentology, 18: 123-128.

Schieber, J., 1990. Significance of styles of epicontinental shale sedimentation in the Belt basin, Mid-Proterozoic of Montana, U.S.A. Sedimentary Geology, 69: 297-312.

Schieber, J., 1994. Reflection of deep vs shallow water deposition by small scale sedimentary features and microfabrics of the Chattanooga Shale in Tennessee. Canadian Society of Petroleum Geologists Memoir, 17: 773-784.

Schieber, J., 1999. Distribution and deposition of mudstone facies in the Upper Devonian Sonyea Group of New York. Journal of Sedimentary Research, 69: 909-925.

Schieber, J., Southard, J.B., 2009. Bedload transport of mud by floccule ripples - direct observation of ripple migration processes and their implications. Geology, 37: 483-486.

Schieber, J., Yawar, Z., 2009. A new twist on mud deposition - mud ripples in experiment and rock record. Sedimentary Record, 7: 4-8.

Schieber, J., Southard, J., Thaisen, K., 2007. Accretion of mudstone beds from migrating floccule ripples. Science, $\mathbf{3 1 8}$ 1760-1763.

Schieber, J., Southard, J.B., Schimmelmann, A., 2010. Lenticular shale fabrics resulting from intermittent erosion of water-rich muds - interpreting the rock record in the light of recent flume experiments. Journal of Sedimentary Research, 80: 119-128.

Seilacher, A., 1991. Events and their signatures - an overview. In: Cycles and Events in Stratigraphy (eds. G. Einsele, W. Ricken and A. Seilacher): 222-226. Springer-Verlag. Berlin, Heidelberg.

Shepard, F.P., 1954. Nomenclature based on sand-silt-clay ratios. Journal of Sedimentary Petrology, 24: 151-158.

Smoleń, J., 2006. Palaeoenvironmental significance of the foraminiferal assemblages from the Middle Jurassic deposits of the Częstochowa area. Volumina Jurassica, 4: 136. 
Stanley, S.M., 1970. Relation of shell form to life habits of the Bivalvia (Mollusca). GSA Memoir, 125: 1-296.

Stow, D.A.V., Piper, D.J.W., 1984. Deep-water fine-grained sediments: facies models. Geological Society Special Publications, 15: 611-646.

Stow, D.A.V., Shanmugam, G., 1980. Sequence of structures in fine-grained turbidites: comparison of recent deep-sea and ancient flysch sediments. Sedimentary Geology, 25: 23-42.

Wetzel, A., 1991. Ecologic interpretation of deep-sea trace fossil communities. Palaeogeography, Palaeoclimatology, Palaeoecology, 85: 47-69.

Wetzel, A., Allia, V., 2000. The significance of hiatus beds in shallow-water mudstones: an example from the Middle Jurassic of Switzerland. Journal of Sedimentary Research, 70: 170-180.

Wignall, P.B., 1989. Sedimentary dynamics of the Kimmeridge Clay: tempests and earthquakes. Journal of the Geological Society, 146: 273-284.

Wright, L.D., Friedrichs, C.T., 2006. Gravity-driven sediment transport on continental shelves: A status report. Continental Shelf Research, 26: 2092-2107.
Zatoń, M., 2011. Diversity dynamics of ammonoids during the latest Bajocian and Bathonian (Middle Jurassic) in the epicratonic Polish Basin. Palaeobiodiversity and Palaeoenvironments, 91: 89-99.

Zatoń, M., Marynowski, L., Szczepanik, P., Bond, D.P.G., Wignall, P.B., 2009. Redox conditions during sedimentation of the Middle Jurassic (Upper Bajocian-Bathonian) clays of the Polish Jura (south-central Poland). Facies, 55: 103-114.

Zatoń, M., Machocka, S., Wilson, M.A., Marynowski, L., Taylor, P.D., 2011. Origin and paleoecology of Middle Jurassic hiatus concretions from Poland. Facies, 57: 275-300.

Zatoń, M., Kremer, B., Marynowski, L., Wilson, M.A., Krawczyński, W., 2012. Middle Jurassic (Bathonian) encrusted oncoids from the Polish Jura, southern Poland. Facies, 58: 57-77.

Ziegler, P.A., 1990. Geological Atlas of Western and Central Europe. Shell Internationale Petroleum Maatschappij BV. 